\title{
Yerel Yönetim Politikalarında Yenilenebilir Enerji
}

\author{
Asmin Kavas Bilgiç \\ TEPAV ve Osman Gazi Üniversitesi \\ ORCID: 0000-0001-8319-7950
}

\author{
Deniz Başoğlu Acet \\ ODTÜ \\ ORCID: 0000-0003-1918-1756
}

\section{Öz}

1950'li yıllarla beraber hızlı bir göç dalgası ile kentleşme ve sanayileşme sürecini yaşamakta olan Türkiye'nin enerjiye yönelik ihtiyaç ve talepleri hızla artmaktadır. Enerjiye yönelik talebin yaklaşık yüzde 75'ini ithal eden ülkemizin enerjide dışa bağımlı olması ve ihracattan elde edilen gelirin enerji ithalatı için harcanması, enerji güvenliğini tehdit eden önemli risklerdendir. Bu risklerin önüne geçebilmek, enerjinin dışa bağhllı̆̆ını en aza indirmek ve sürdürülebilir bir büyüme sağlayabilmek için Türkiye gibi gelişmekte olan ülkeler, özellikle 2000'li yıllarla birlikte enerjinin verimli kullanımı ve alternatif enerji kaynaklarına yönelik politikaların geliştirilmesi için çalışmalarına hız kazandırmışlardır. Yapılan yasal düzenlemelere göre öngörülen faaliyetlerin uygulamaya geçirilmesi ve tedbirlerin alınmasında tek başına merkezi yönetim kuruluşları ve onların taşra birimleri yeterli görülmemektedir. Türkiye'de bugün nüfusun neredeyse yüzde 93'ünün kent yönetimi olan belediye sinırlar içerisinde, bunun yüzde 77,6'sının büyükşehir belediyele sinırları içerisinde yaşadığı göz önünde bulundurulduğunda, enerji ihtiyacının karşılanması ve enerji verimliliğinin sağlanmasında, yerelden merkeze doğru ivmelenecek enerji politikalarının hayata geçirilmesinde, yerel yönetimlere de büyük ödevler, görevler ve sorumluluklar düşmektedir. "Yerel Yönetim Politikalarında Yenilenebilir Enerji" başlıklı bu çalışmanın da temel amacı, Türkiye'de enerji politikalarının hayata geçirilmesinde önemli bir yere sahip olan yerel yönetimlerin bu alana yönelik politika ve faaliyet alanlarının tespit edilmesi ve ilgili tüm paydaşların katılımlarının să̆lanabileceği yeni bir politika diyaloğu geliştirilmesine katkı sunmaktır.-

Anahtar Kelimeler: Enerji, enerji verimliliŭi, yenilenebilir enerji, yerel yönetimler, politika belgeleri. 


\title{
Renewable Energy in Local Governments' Policies
}

\author{
Asmin Kavas Bilgiç \\ TEPAV \& Osman Gazi University \\ ORCID: 0000-0001-8319-7950
}

\author{
Deniz Başoğlu Acet \\ METU \\ ORCID: 0000-0003-1918-1756
}

\begin{abstract}
With the rapid urbanization, migration from rural to urban areas and industrialization since 1950s, need and demand for energy is ever-increasing in Turkey. For Turkey, who is importing approximately 75 percent of the demanded energy; external dependence, the expenditure of the income from exports for the energy imports, threaten the energy security. To address the mentioned goals of minimizing external dependence, Turkey has accelerated the creation and implementation of policies on alternative energy resources and the efficient use of energy starting from 2000s. Accordingly, these legal arrangements and related actions cannot be carried out adequately enough by central government bodies and their provincial units alone. Approximately 93 percent of the population in Turkey today is living within municipal boundaries, of which 77.6 percent live in metropolitan municipalities boundaries, local governments have a great deal of responsibilities related to energy supply and efficiency, as well as the realization of the energy policies that can be accelerated from part to whole and from local to center. The main purpose of this study is to determine the energy-related political activity areas of local governments and to contribute to the development of a new political dialogue which engage all related stakeholders.
\end{abstract}

Keywords: Energy, energy efficiency, renewable energy, local governments, policy papers. 


\section{Giriş}

1973 yılında yaşanan Petrol Krizi'nin ardından neredeyse tüm dünya ülkeleri tarafından enerjinin önemi ve enerjiye duyulan ihtiyaç tartışılmaya başlanmıştır. Bu tarihten itibaren gelişmiş ülkeler başta olmak üzere birçok ülke enerji kaynaklarını çeşitlendirmeye, alternatif enerji kaynakları yaratmaya ve enerjinin verimli kullanımına yönelik politika arayışları içine girmişlerdir. Kentleşme, bilgi teknolojisinin çeşitlenmesi, üretim ve tüketim alışkanlıklarının değişmesi gibi faktörler, enerjiye yönelik talep ve ihtiyaçların artmasına sebep olmaktadır. Sürdürülebilir bir büyümenin gerçekleştirilebilmesi için de birçok ülke, enerji talep ve ihtiyaçlarını en uygun ölçekte karşılamayı temel hedef haline getirmiştir. Ülkeler, kendi sınırları içerisinde bu ihtiyaçlarını karşılayamamaları halinde enerjide dışa bağımlı olmaktadırlar. Son yıllarda yapılan görgül (ampirik) araştırmalar da sanayileşmenin ve büyümenin önündeki en önemli engellerden birisini, enerjide dışa bağımlılı̆̆ın yüksek olmasına bağlamaktadır. Bu çalışmalar, büyüme ile enerji tüketimi arasında doğru orantılı bir ilişkinin olduğunu ve büyümenin dışa bağımlılığı en aza indirgeyecek şekilde, enerji tedariki önkoşuluyla gerçekleşebileceğini göstermektedirler. 1950'li yıllarla beraber hızlı bir göç dalgası ile kentleşme ve sanayileşme sürecini halen yaşamakta olan Türkiye'nin de enerjiye yönelik ihtiyaç ve talepleri hızla artmaktadır. Enerjiye yönelik talebin yaklaşık olarak yüzde 75'ini ithal eden ülkemizin enerjide dışa bağımlı olması, ihracattan elde edilen gelirin enerji ithalatı için harcanması ve enerji kaynaklarının büyük oranda fosil yakıtlara dayanması, enerji güvenliğini tehdit eden önemli risklerdendir. Bu risklerin önüne geçebilmek, enerjinin dışa bağımlılığını en aza indirmek ve sürdürülebilir bir büyüme sağlayabilmek için Türkiye gibi gelişmekte olan ülkeler, özellikle 2000'li yıllarla birlikte enerjinin verimli kullanımı ve alternatif enerji kaynaklarına yönelik politikaların geliştirilmesi için çalışmalarına hız kazandırmışlardır.

Sürekli artan enerji talebinin başta yerel kaynaklar eliyle karşılanması, enerjiye yönelik altyapı olanaklarının artırılması, enerjinin etkin kullanımı, enerji maliyetlerinin ekonomi üzerindeki yükünün hafifletilmesi, çevrenin korunması için enerji kaynaklarının ve enerjinin kullanımında verimliliğin artırılması amacıyla 2000'li yıllar itibariyle, Türkiye'de yasal çerçeve ve kurumsal alanda önemli düzenlemeler yapılmıştır. Ulusal ölçekte 2001 yılından günümüze kadar yapılan yasal düzenlemeler merkeziyetçi anlayıştan farklı bir bakışı yansıtmakta; çok-disiplinli çalışmalar gerektiren konular, aynı za- 
manda çok ortaklı ve çok kademeli yapılanmaları oluşturmaktadırlar. Yapılan yasal düzenlemelere göre öngörülen faaliyetlerin uygulamaya geçirilmesi ve tedbirlerin alınmasında tek başına merkezi yönetim kuruluşları ve onların taşra birimleri yeterli görülmemektedir. Türkiye'de bugün nüfusun neredeyse yüzde 93'ünün kent yönetimi olan belediye sinırları içerisinde, bunun yüzde 77,6'sının büyükşehir belediyelerinde; geri kalan yüzde 22,34'ünün ise diğer belediye sınırları içerisinde yaşadığı göz önünde bulundurulduğunda, enerji ihtiyacının karşılanması ve enerji verimliliğinin sağlanmasında, yerelden merkeze doğru ivmelenecek enerji politikalarının hayata geçirilmesinde, yerel yönetimlere de büyük ödevler, görevler ve sorumluluklar düşmektedir. Uluslararası arenada da enerji üretiminin ve verimliliğinin yerel yönetimlerin sorumluluğunda olması çok sık rastlanan bir olgudur. Yapılan araştırmalara göre Almanya, Yeni Zelanda, Danimarka, Fransa gibi ülkelerde yerel yönetimler, yenilenebilir enerji yatırımlarının büyük çoğunluğunu ellerinde tutmakta, merkezi olmayan enerji altyapılarının kontrolünü sağlamakta ve özel imtiyazları sona erdirerek yerel enerji altyapılarını devralmaya başlamaktadırlar. Türkiye' de ise 5216 sayılı Büyükşehir Belediye Kanunu, 5393 sayılı Belediye Kanunu ve 5302 sayılı İl Özel İdaresi Kanunu çerçevesinde görev alanları tanımlanan yerel yönetimlerin enerji alanına yönelik yürütmüş oldukları birçok politika ve faaliyet alanları, yörenin stratejik öncelik ve hedefleri göz ardı edilerek hazırlanmış; bu politika ve faaliyet alanları genellikle kurum içi performans göstergelerinin iyileştirilmesinden öteye gidemediği bulgusuna ulaşılmıştır.

"Yerel Yönetim Politikalarında; Enerji" başlıklı bu çalışmanın da temel amacı Türkiye'de enerji politikalarının hayata geçirilmesinde önemli bir yere sahip olan yerel yönetimlerin bu alana yönelik politika ve faaliyet alanlarının tespit edilmesi ve ilgili tüm paydaşların katılımlarının sağlanabileceği yeni bir politika diyaloğu geliştirilmesine katkı sunmaktır.

Çalışma kapsamında, derinlemesine araştırma yönetiminden yararlanılarak, Türkiye'de nüfusun ve enerji ihtiyacının büyük bir kısmına ev sahipliği yapan 30 büyükşehir belediyesinin enerji politika ve faaliyet alanları; (1) 20142019 yılları arasını kapsayan stratejik planlar, (2) 2014-2019 yılları arasında her yıl düzenli aralıklarla yayımlanan performans programları, (3) 2014-2019 yılları arasında her yıl düzenli aralıklarla yayımlanan faaliyet raporları üzerinden tartı̧ılacak ve (4) uluslararası iyi uygulama örnekleri üzerinden karşılaştırmalı analizlerle detaylandırılacaktır. Çalışma süresince yerel yönetimler düzeyinde yenilenebilir enerji politikaları ve enerjinin sürdürülebilir kullanımına dair yapılan atıflar özel olarak incelenecektir. 
Çalışmanın bulgularının değerlendirilmesi kısmında Türkiye'de 30 büyükşehir belediyesinin enerji alanına yönelik politika ve faaliyet alanlarının yeterli düzeyde olmadığı, hatta birçoğunun kurum içi performans göstergelerinin iyileştirilmesinden öteye gidemeyen hedef ve politikalardan oluştuğu hipotezi doğrulanarak, bulgular ölçeğinde yansitılmaya çalışılacaktır.

Çalışmanın sonuç kısmında ise Türkiye'nin ve uluslararası iyi uygulama örneklerinde yerel birimlerin enerji alanına yönelik hedef, uygulama ve politikaları da dikkate alınarak, Türkiye' de yerel yönetimler için enerjiye yönelik hizmet alanlarında standartlaşmayı getirecek ve yerel yönetimlerin bu alana yönelik performanslarının değerlendirilebilmesine kaynaklık edecek, iki aşamalı yol haritasına yer verilecektir. Yukarıda da belirtildiği gibi enerji kaynakları bakımından yüzde 75'ler seviyesinde dışarıya bağımlı olan ülkemizde, enerji politikalarının hayata geçirilmesinde önemli bir yere sahip olan yerel yönetimlere büyük ödevler ve görevler düşmektedir. Bu çalışma kapsamında da yereldeki çalışmaların yönlendirilmesi ve izlenmesi açısından, yerel yönetimlerin enerji alanındaki eylemlerinin, politika ve stratejiler doğrultusunda geliştirilmesinin öneminin vurgulanması hedeflenmektedir.

\section{Yenilenebilir Enerji Kaynağı ve Dünyada Enerjinin Sürdürebilir Gelişme Eksenleri Kapsamında Ele Alınışı}

Enerji, geçmişten günümüze insanlar için öncelikli temel ihtiyaçlardandır. Aynı zamanda enerji, yaşam şartlarının, ekonomik ve toplumsal kalkınmanın en önemli girdilerinden ve göstergelerindendir. Bununla birlikte küresel ölçekte, ekonomilerin hızlı bir şekilde büyümesi nedeniyle enerji talebi günden güne artmakta, bu talebin karşılanmasında ise mevcut durumda en yaygin kullanım alanına sahip fosil kaynaklar tercih edilmektedir. Mevcut durumda küresel enerji karmasının yaklaşık yüzde 81'ini meydana getiren fosil kaynakların doğada sınırlı olarak bulunması (IEA, 2018), bu kaynaklara alternatif oluşturabilecek diğer enerji kaynaklarına yönelimi artıran faktörlerden biri$\operatorname{dir}($ Avcıoğlu, 2017).

Günümüz enerji ihtiyacını karşılayabilen enerji kaynakları, enerjinin oluşumu ve özelliklerine göre; yenilenebilir olmayan (konvansiyonel) ve yenilenebilir enerji kaynakları olmak üzere ikiye ayrılır. İlki, dünya genelinde enerji kaynaklarının sınırlı olması ve hatta tükenebilir olması, yine yüksek talebe bağlı olarak, kaynak oluşumundan çok daha kısa sürede tüketilebilir olması dolayısıyla yenilenebilir olmayan enerji kaynakları olarak isimlendirilir. 
Buna göre mevcut enerji karmasında önemli yeri bulunan fosil yakıtlar (petrol, doğal gaz ve kömür) ve nükleer enerji, bu sınıfa dahil olan enerji kaynaklarıdır. Yenilenebilir enerji kaynakları ise hem oluşumu hem de kaynağın doğal ve kısa bir zaman içerisinde yenilenebilir olması bakımından, yenilenebilir olmayan enerji kaynaklarından ayrılır. Güneş, rüzgar, jeotermal, hareketli su kaynakları ve dalga, yenilenebilir enerji kaynaklarını oluşturmaktadır. Yenilenebilir ve yenilenebilir olmayan tüm enerji kaynakları, doğada var olan kaynaklar olduğundan, birincil enerji kaynakları olarak adlandırılır. Yine, hem yenilenebilir hem de fosil ya da nükleer enerji kaynaklarının dönüştürülmesiyle ortaya çıkan, günlük yaşamımızda doğrudan kullandığımız elektrik ya da ısı gibi enerjiler ise ikincil enerji kaynakları olarak adlandırılır (Ad1yaman, 2012).

Toplumların şekillenmesinde önemli bir rolü bulunan enerji, aynı zamanda mevcut yaşayışımızın meydana gelmesinde de önemli bir role sahiptir. Sanayi Devrimi'ne kadar olan dönemde insanlar, genellikle odun, tezek gibi biyolojik kaynaklı enerji kaynaklarından faydalanmaktadır. Buharlı motorların keşfiyle, yenilenebilir olmayan enerjilerin kullanımı da yaygınlaşmaya başlamıştır. Endüstriyel çağda ise teknolojik gelişme ve enerji ihtiyacının hızla artması sonucu petrol kaynaklarından yararlanılmaya başlanmıştır.

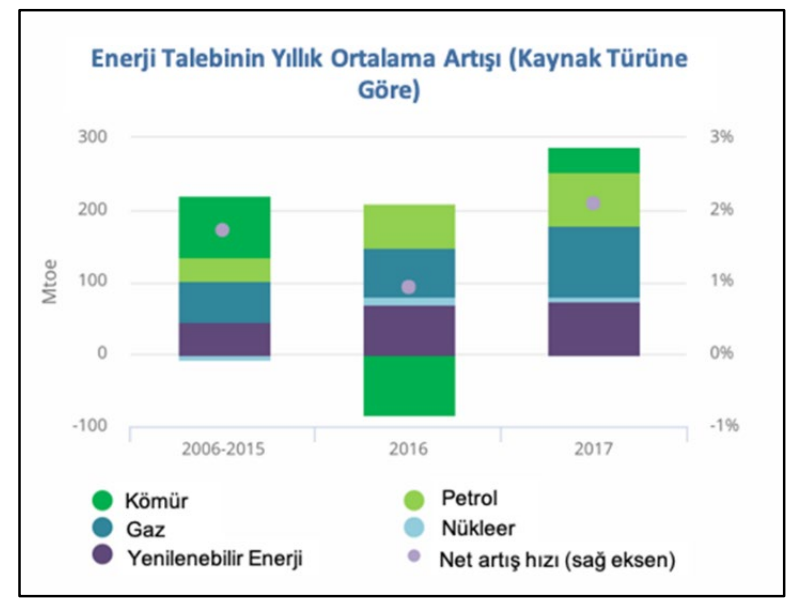

Şekil 1. Enerji Talebinin Yıllık Ortalama Artışı

Kaynak: IEA, 2018'den alıntılanmış ve değiştirilmiştir.

Enerji talebi, nüfus artışına, kentleşmeye, teknolojik gelişmelere, makineleşmeye ve sanayileşmeye koşut olarak, hem küresel hem de bireysel ölçekte artış göstermektedir (Adıyaman, 2012; Enerji ve Tabii Kaynaklar Bakanlığı, 2010). Şekil 1'de gözlemlenebileceği gibi 2006 ile 2015 yılları arasında nükleer 
enerji hariç tüm enerji kaynaklarına talep, yıllık ortalama yüzde 2 civarında artış göstermektedir. Uluslararası Enerji Ajansı verilerine göre 2016 yılında enerji artış hızı yavaşlayarak yıllık yüzde 1'e gerilerken; 2017 yılında bir önceki yıla kıyasla 2 kat artarak yüzde 2.1'e ulaşmıştır. Tüm enerji türleri arasında talebin en çok artığı kaynaklar ise doğal gaz ve yenilenebilir enerjidir (IEA, 2018).

\section{Enerjinin Çevresel, Toplumsal ve Ekonomik Etkileri}

Tüm enerji kaynakları, ister fosil ister yenilenebilir kaynaklar olsun, türüne ve tüketim miktarına göre değişen ölçekte çevresel etkiye sahiptir. Fosil yakıtların yoğunlukta olduğu mevcut küresel enerji karmasında (energy mix), çevresel etki, hem çeşitlenmekte hem de artmaktadır. Buna göre günümüzde enerji ile ilişkilendirilebilecek en önemli çevre problemleri; i) hava ve su gibi doğal kaynakların kirliliği, ii) su ve arazi gibi kısıtlı doğal kaynakların verimsiz kullanımı, iii) biyoçeşitliliğin ve dolayısıyla ekosistem hizmetlerinin azalması, iv) fosil kaynaklı yakıt kullanımının artması ve insan kaynaklı iklim değişikliğidir. 2014 yılında Hükümetlerarası İklim Değişikliği Paneli tarafından hazırlanan rapora göre toplam küresel sera gazı emisyonlarının yüzde 35'i enerji arzı ile ilişkilendirilmektedir (IPCC, 2014).

Enerjinin insan sağlığı üzerinde de önemli etkileri bulunmaktadır. Fosil yakıt kaynaklı küresel hava kirliliği ve karbondioksit salımı, en çok çocukları ve gençleri etkilemektedir (Perera, 2018, s. 16). Dünya Sağlık Örgütü raporlarına göre fosil yakıt yoğun enerji karmasına bağlı hava kirliliği nedeniyle 2010 yılında 3.1 milyon bebek hayatını kaybetmiştir (Lim vd., 2010, s. 380). Bu noktada sağlık sorunları kaynaklı ekonomik etkilerin de hesaplanamayacak ölçüde büyük bir etki yarattığını da vurgulamak gerekir. Özellikle gelişmekte olan ülkelerde, enerji arzı ve karması ile ekonomik kalkınmanın en önemli göstergesi gayri safi yurt içi hasıla (GSYİH) arasında önemli bir ilişki vardır. Bununla birlikte üretimle ilişkili olan ekonomik kalkınmanın, üretimin temel ihtiyacı olan enerji ile de yakın ilişkisi bulunmaktadır (Yanar ve Kerimoğlu, 2011, s.198). Enerji arzı için yeterli yerel kaynakların bulunmadığı ve talebin yerelden karşılanamadığı durumlarda ise ülkeler, ihtiyaç duydukları enerjiyi ithal etmekte; buna bağlı olarak da enerjide dışa bağımlılık ortaya çıkmaktadir.

Enerji kullanımına dair tüm etkiler, artan enerji ihtiyacı ile mevcut enerji karmasında daha da ağırlaşmaktadır. Hem artan talebin karşılanması hem de ortaya çıan çevresel, ekonomik ve sosyal etkilerin yansımalarının en aza 
indirilmesi için, dünya tarihinde birden fazla kez gerçekleşmiş bir fenomenden, enerji dönüşünden bahsetmek gerekir. Enerji dönüşümü literatürde, küresel, bölgesel ya da yerel ölçekte bir ya da bir dizi enerji kaynağı ve teknolojisine bağımlı ekonomik bir sistemden, bir diğerine geçiş olarak tanımlanmıştır (Fouquet ve Pearson, 2012, s.5). Yeni ekonomik modelin, gelişmekte olan teknolojiler sayesinde artan ve değişen enerji ihtiyacını kısmen ya da tamamen karşılayabilecek bir model olması beklenir. Yakın tarihli bir örnek vermek gerekirse, 1973 yılında yaşanan petrol krizi ve bağlantılı ekonomik sıkıntılar ile birlikte; pek çok Avrupa Birliği ülkesinde; öncelikle enerjide dışa bağımlığı ve petrol ithalatını azaltmak amacıyla, nükleer enerji santralleri kurulmaya başlanmıştır. Ancak nükleer enerji santralleri ile küresel ölçekte yaşanan çevresel kaynaklı sıkıntılar, toplumsal bir hassasiyetin ortaya çıkmasına neden olmuştur. Teknolojinin gelişmesi ile beraber bu hassasiyet, yenilenebilir enerji kaynaklarına olan ilgiyi artırmış ve bu durum yenilenebilir enerji kaynaklarının enerji üretimindeki paylarını artırmayı başarmıştır. Görüldüğü üzere, gelecekte gerçekleşme olasıllı̆ı bulunan benzeri krizlere karşın yenilenebilir enerji alanına doğru önemli bir dönüşüm gerçekleşmekte ve fosil kaynakların tümdeki payı azalmaktadır (van de Ven, Fouquat, 2017, s.210).

Günümüzde, küresel ölçekte yaşanmakta olan bu enerji dönüşümü iklim değişikliği tartışmaları ile birlikte, tarihte yaşanan dönüşümlerden farklı bir şekilde hız kazanmaktadır. Küresel ölçekte gerçekleşmekte olan enerji dönüşümünün, yaygın olan fosil yakıtlar kaynaklı enerji karmasından; (yani karbon-yoğun bir enerji karmasından) yenilenebilir enerji kaynaklarına (yani düşük ya da sıfır karbonlu yakıtların) doğru ağırlığının artığı bir modele doğru geçişi beklenmektedir. Bu noktada, yenilenebilir kaynakların ve yeni düşük karbonlu sistemlerin yaygınlaştırılması söz konusu olabilir.

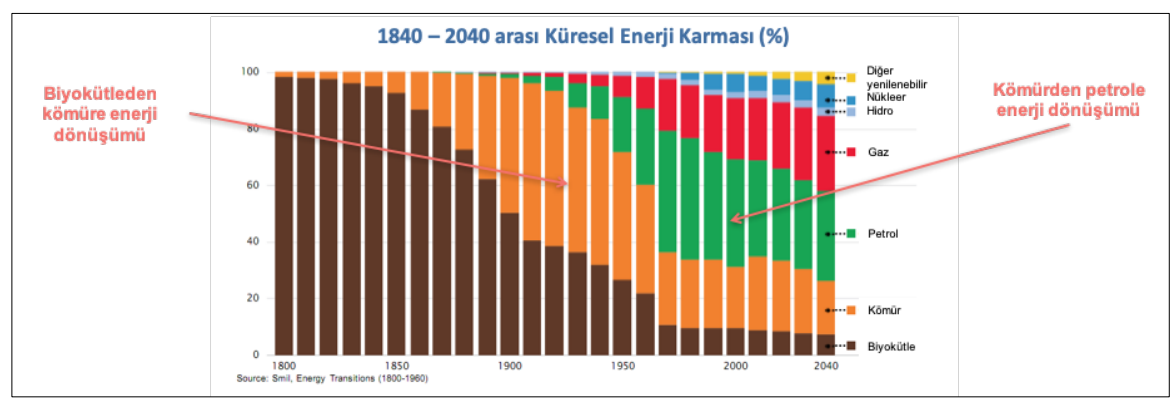

Şekil 2. 1840-2040 yılları arası Küresel Enerji Karması

Kaynak: http://www3.weforum.org/docs/WEF_EN_EnergyVision_Report_2013.pdf 


\section{Yerel Yönetimlerin Enerji Dönüşümündeki Rolü}

Birleşmiş Milletler' in 2018 yılında yayınladığı rapora göre şehirler, dünya nüfusunun yüzde 55'ine ev sahipliği yapmaktadır (BM, 2018). 2050 yılında bu oranın yüzde 68'e ulaşması beklenmektedir (BM, 2018). Yine Hükümetlerarası İklim Değişikliği Paneli tarafından 2014 yılında hazırlanan rapor, son enerji kullanımına bağlı CO2 emisyonlarının yüzde 71-76'sının; küresel enerji tüketiminin ise yüzde 67-76'sının şehirlerde gerçekleştiğini ortaya koymuştur (IPCC, 2014b). Uluslararası Yenilenebilir Ajansı' nın 2016 yılında yayınlanan raporuna göre ise 2030 yılına gelindiğinde, şehirlerdeki enerji ihtiyacının, yüzde 35 artacağı öngörülmektedir (IRENA, 2016b). Artan enerji ihtiyacı ile beraber iklim değişikliği de şehirlerdeki yaşamı olumsuz yönde etkilemektedir. İklim değişikliğine bağlı yağış desenlerinin değişmesi, su seviyelerinin yükselmesi ve mevsimlerde meydana gelen kaymalar, özellikle geçim kaynakları tarıma dayalı olan şehirlerde, yerel ekonomi ve yaşam standartlarını zorlaştırmaktadır. Bu bağlamda şehirlerde enerji ihtiyacının karşılanması ve iklim değişikliğinin olumsuz etkilerinin azaltılmasına yönelik yerel düzeyde alınan kararlar ve önlemler de günden güne önem kazanmaktadır (van Staden, 2017, s.211). Enerji kullanımının yoğunlaştığı şehirlerde, iklim değişikliği ile mücadele politikaları eşliğinde alınacak kararlar, ulusal ve küresel düzeyde iklim değiş̧ikliği ile mücadele ve adaptasyon için gerekli görülmektedir (van Staden, 2017) . Bu aşamada gelişmiş ülkeler başta olmak üzere birçok ülkede, yerel yönetimlerin etkin bir politika yürütebilmesi için ulusal düzeyde izin, yetki veren ve finansman desteği sağlayabilen çerçeve hedeflerinin geliştirilmesi üzerinde durulmaktadır (van Staden, 2017, s.214). Bunun sonucu olarak da kentler ve yerel otoriteler, küresel sürdürülebilir kalkınma ve iklim değişikliğine dair çabaların büyük ölçüde belirleyicisi olmaktadırlar (IRENA, 2016b).

Enerji dönüşümü alanında yapılan birçok çalışmada, sürdürülebilir, düşük karbonlu ekonomiye geçişte yerel yönetimlerin kilit rolde olduğu belirtilmektedir (AP, 2018; IEA, 2016a; IRENA, 2016a). Yerel yönetimlerin, sürdürülebilir enerjiye geçişteki rolü, Sürdürülebilir Kalkınma Hedefleri'nin 11. Maddesi olan "Sürdürülebilir Şehirler ve Yaşam Alanları" ile de yakından ilişkilidir (BMKP, 2018). Yine Paris Antlaşması da ulusal iklim değişikliği ve sürdürülebilirlik hedeflerine ulaşılmasında yerel yönetimlerin önemine vurgu yapmaktadır (BM, 2015). Benzer şekilde bu alana ilişkin yapılan birçok araştırma da yerel ölçeği, enerji maliyetlerinin düşürülmesi, enerji verimliliğinin sağlanması ve yenilenebilir enerji politikalarının uygulamaya 
konulması bakımından en uygun ölçek olarak görmektedir (Vidalenc, 2017).

Enerji dönüşümünün, fosil yakıt kaynaklı karbon-yoğun bir enerji sisteminden daha düşük karbonlu bir sisteme geçişi ile birlikte, yenilenebilir enerji türlerinden en az birinin yerel ölçek içerisinde verimli bir halde bulunması varsayımı; yerel yönetimler bakımından yenilenebilir enerji çalışmalarını uygulanabilir kılmaktadır. Bu bağlamda birden fazla yenilenebilir enerji kaynaklarının bulunduğu bölgelerde, yenilenebilir enerji karmaları oluşturulabilir. Bu kaynakların belirlenmesinde ise yerel yönetimlere büyük görev ve sorumluluklar düşmektedir (van Staden, 2017, s.213). Bu alanda yerel yönetimler, enerjinin verimliliğinin artması ve yerel ölçekte enerji maliyetlerinin düşürülmesi amacıyla, çok çeşitli yerel düzeyde kararlar ve önlemler almaktadırlar. Yerel yönetimler, yerelde alınacak olan bu aksiyonların doğrudan ya da dolaylı etkilerinin neler olacağını, bu aksiyonların ne şekilde finanse edileceğini, vatandaş, iş ve sanayi sektörleri için yaşam kalitesinin ne şekilde iyileştirileceğine, merkezi yönetimlere oranla daha fazla hakimdirler. Bu halde, paydaşların (vatandaşlar, kamu ve özel sektör ile sivil toplum örgütleri) katılımıyla yerelde alınacak aksiyonlar; yerel yönetimlerin için enerji dönüşümü sürecinde başarıya ulaşmak için kritik faktörlerdir.

\section{İyi Uygulama Örnekleri Üzerinden Yenilenebilir Enerji Politikaları}

Türkiye'deki yerel yönetimlere yönelik iyi uygulama örneklerinin belirlenmesi kapsamında çalışmanın bu kısmında, hem iklim değişikliği hem de yenilenebilir enerji çalışmalarında öncü olan Avrupa Birliği üye ülkelerinin, ulusal enerji planları, yerel enerji planları ve yerel enerji uygulamaları konularında bir literatür çalışması yürütülmüştür. Bu doğrultuda, diğer ülkelerden ayrışarak yenilikçi bir yerel enerji planlaması çalışması yürüten Fransa ile uzun yıllardır yenilenebilir enerji konusunda yerel yönetimler, kooperatifler ve sivil toplum eliyle, yaygın bir şekilde yenilenebilir enerji uygulamaları gerçekleştiren Almanya; Türkiye için önerilecek olan 2 aşamalı yol haritası için iyi örnekleri teşkil etmektedir.

\section{Planlama Alaninda En İyi Örnek: Fransa}

Fransa, yerel yönetimlerin stratejik enerji planlamasında Türkiye için önemli bir rol model teşkil etmektedir. 2000'li yıllara kadar Fransa' da enerji 
üretimi, dağıtımı ve ulaşımı, merkezi altyapı ve organizasyonlar eliyle gerçekleştirilmekteydi. Avrupa Birliği tarafından 2003 ve 2006 yıllarında yayınlanan iki direktif (19 Aralık 1996 tarihli 96/92 sayılı direktif ve 26 Haziran 2003 tarihli iç elektrik piyasası hakkındaki 2003/54 sayılı direktif) doğrultusunda Fransa, 2003 ve 2004 yıllarında çıkarılan yasalar ile enerji piyasasının liberalleşmesi yolunda ilk adımı atmıştır (eni Fransa, 2017). 2014 yılında yürürlüğe giren MAPTAM Yasası (Bölgesel Kamu Eyleminin Modernizasyonu ve Büyükşehir Alanlarının Onaylanması İle İlgili Yasa) ve NOTRe Yasası (Cumhuriyetin Yeni Toprak Örgütü Kanunu) yerel yönetimlere, sürdürülebilir ulaşımın planlanması ve yönetimi, biyoçeşitliliğin korunması, sosyal hizmetler ve enerji dönüşümü alanlarında önemli yetkiler ve sorumluluklar yüklemiştir (Vidalenc, 2017; IEA, 2016b). Bunun yanı sıra Fransa Hükümeti, 2015 yılında Paris Antlaşması'na da ev sahipliği yapacağı dönemde, ilk ulusal yenilenebilir enerji ve enerji dönüşümü yasasını çıkartmıştır. 2015 yılı Ağustos ayında yürürlüğe giren Yeşil Büyüme için Enerji Dönüşümü Yasası ile 2030 yılında yeşil ekonomik büyüme için enerji dönüşümüne dair enerji politikalarının çerçevesi ortaya konulmuştur. Bu yasanın 5 ana aksiyon prensibi ise; i) binalarda enerji verimliliğinin ve düşük enerji kullanımını, talep-odaklı enerji yönetimini ve tüketici entegrasyonunu sağlanmak; ii) vatandaşlar, şirketler ve yerel otoritelerin işbirliğini sağlamak; iii) enerji maliyet ve fiyatlarında şeffaflığı güvence altına almak, iv) enerji alanında çalışma ve araştırmalar yürütmek, v) enerji karmasını çeşitlendirmek, fosil yakıtların payını azaltmak, elektrik üretiminde kaynak çeşitliliğini arttırmak ve yenilenebilir enerjinin payını arttırmak, olarak s1ralanabilir (IEA, 2016b). Bu yasanın bir parçası olarak enerji ve iklim değişikliği konularında 2030 yılına kadar, sera gazı emisyonlarının yüzde 40 azaltılması, yenilenebilir enerjinin toplam enerji tüketimindeki payının yüzde 32'ye çıartılması ve fosil yakıt tüketiminin yüzde 30 azaltılması gibi bağlayıcı hedefler de belirlenmiştir (OECD, 2016). Yine, Yeşil Büyüme için Enerji Dönüşümü Yasası kapsamında, enerji dönüşümünde bölgelerin ve şehirlerin rolünün güçlendirilmesi adına, çeşitli alt plan ve tanımlar yapılmıştır. Bunlar; pozitif enerji bölgeleri oluşturulması ile yereldeki planlama ve yönetimin çerçevesini belirleyen "Yerel Hava İklim ve Enerji Aksiyon Planları"dır (OECD, 2016). Yeşil Büyüme için Enerji Dönüşümü Yasası'nın yürürlüğe girmesini takip eden 1 yıl içinde (2015 -2016), 400 yerel otorite, 500 milyon Euro fon/finansman alarak yaklaşık 260 bin ton karbon salımı azalımı, 2.3 GW'lık panel üretim hattı (PV) yatırımı ve 350 kamu binasının enerji verimliliği analizi ve dönüşümünü gerçekleştirmiştir (MEEM, 2016). 
Tablo 1. Yerel Hava, İklim ve Enerji Planı: Ana Adımlar ve Göstergeler

\begin{tabular}{|c|c|c|}
\hline \multicolumn{3}{|c|}{ Yerel Hava, İklim ve Enerji Eylem Planı } \\
\hline $\begin{array}{l}\text { Aşama } 1 \\
\text { Bölgenin enerji } \\
\text { bakımından mevcut } \\
\text { durum araştırması }\end{array}$ & \begin{tabular}{|l|} 
Aşama 2 \\
Bölgenin potansiyelinin \\
anlaşılması
\end{tabular} & $\begin{array}{l}\text { Aşama } 3 \\
\text { Strateji ve Eylem } \\
\text { Planlaması }\end{array}$ \\
\hline $\begin{array}{l}\text { - Enerji tüketim ve } \\
\text { üretiminin } \\
\text { anlaşılması } \\
\text { - Enerji ağları ve } \\
\text { şebekelerin } \\
\text { haritalandırıması } \\
\text { - Yerel yönetimlere } \\
\text { düşen } \\
\text { sorumlulukların } \\
\text { araştırılması ve } \\
\text { kavranması }\end{array}$ & $\begin{array}{l}\text { - Yerel bir öngörü } \\
\text { çalısmasının } \\
\text { yapılması } \\
\text { (demografik, } \\
\text { ekonomik, şehirleşme } \\
\text { ve planlama vs.) } \\
\text { - Enerji verimliliği ve } \\
\text { yenilenebilir enerji } \\
\text { potansiyelinin } \\
\text { değerlendirilmesi, } \\
\text { ağların ve şebekelerin } \\
\text { buna göre } \\
\text { haritalandırıması }\end{array}$ & $\begin{array}{l}\text { - Uzun vadeli } \\
\text { senaryoların } \\
\text { oluşturulması } \\
(2030,2050) \\
\text { - Paydaşların } \\
\text { mevcut ve } \\
\text { potansiyel } \\
\text { katkılarını içeren } \\
\text { kısa ve orta } \\
\text { vadeli eylem } \\
\text { planlarının } \\
\text { olussturulması (5 } \\
\text { yillık vs.) } \\
\text { - Bölgeye özel } \\
\text { göstergelerin } \\
\text { belirlenmesi } \\
\text { - Izleme } \\
\text { sistemlerinin } \\
\text { belirlenmesi }\end{array}$ \\
\hline Göstergeler & \multicolumn{2}{|c|}{$\begin{array}{l}\text { - Yerel enerji aksiyonlarının iklim değişikliği } \\
\text { tartışmalarından arındırılması için "iklim } \\
\text { göstergeleri" yerine "sosyo-ekonomik } \\
\text { göstergeler" } \\
\text { Enerji endüstrisi istihdamı, yerel/bölgesel enerji } \\
\text { maliyetleri gibi }\end{array}$} \\
\hline
\end{tabular}

Kaynak: Vidalenc, 2017'den alınmış ve değiştirilmiştir

2017 yılında Fransız Çevre ve Enerji Ajansı (ADEME), Fransa'daki yerel yönetimler için bölgesel delagasyonlar yoluyla, Yerel Hava, İklim ve Enerji Eylem Planları'nın ne şekilde olması gerektiğine dair bir öneri belgesi hazırlamıştır (Vidalenc, 2017). Bu öneri belgesine göre Yerel Enerji Planlaması, yerel düzeyde enerji dönüşümünü uygulamak için bir eylem planı niteliğindedir. Tablo 1'de de gösterildiği üzere, Yerel Hava, İklim ve Enerji Planı, yerel yönetimler tarafından düzenlenen, enerji üretimi ve tüketimini katılımcı bir yöntem ile ele alan, yerel düzeyde muhtemel enerji karmasını haritalandıran, mevcut durumun kısa orta ve uzun vadeli ihtiyaç ve üretimini değerlendiren başlıklar hakkında detaylı çalışmalar içermektedir (Vidalenc, 2017). Bu çerçevede yerel yönetimler tarafından hazırlanan Yerel Hava, İklim ve Enerji Planları, i)enerji arzı, tüketimi ve ağlarının analiz edilmesini ve haritalandırılmasını, ii) enerji karmasının planlanmasını ve fizibilite çalışmalarının yapılmasını, iii) enerji verimliliği potansiyelinin analiz edilmesini, iv) enerji projeksiyonlarının (kısa, orta ve uzun vade) ve hedeflerin belirlenmesini, v) ulusal hedefleri gözeten, teknik, finansal ve ekonomik faktörleri kapsayan ve tüm paydaşları içeren bir yol haritası şeklindedir. Tüm bunların yanı sıra, planlarda yer alan faaliyetlerin performanslarını ölçmek 
için önerilen göstergeler ise yerel enerji aksiyonlarının iklim değişikliği tartışmalarından arındırılması için "iklim göstergeleri” yerine, enerji endüstrisi istihdami, yerel ya da bölgesel enerji maliyetleri gibi "sosyo-ekonomik göstergeler" arasından seçilmektedir (Vidalenc, 2017).

Tüm bunlardan hareketle 2018 tarihli Paris şehrinin Hava, iklim ve Enerji Eylem Planı, belirtilen yönlendirmelere göre incelenmiştir. 2018 tarihli planda, enerji üretim ve tüketiminin birlikte değerlendirildiğini, yerel yönetimin hem enerji üretimi hem de verimliliği konularında sorumluluğunun net bir şekilde tanımlandığı, yerel bir öngörü çalışması ile kısa, orta ve uzun vadeli hedeflerin de ölçülebilir bir şekilde hazırlandığı görülmektedir. Bu bulgu aşağıda oluşturulan Tablo 2'ye de yansıtılmıştır. Bunun dışında belgede haritalandırma ve şehir bölge planları entegrasyonu için 2018 yılı itibariyle hazırlanacak ayrı bir enerji master planından da bahsedilmektedir. Yine planın başarısını ölçecek olan izleme sistemi ve göstergelerin de her yıl hazırlanacak yıllık enerji ve iklim raporlarında yer alacağı belirtilmiştir (Vidalenc, 2017).

Tablo 2. Paris Hava, iklim ve Enerji Eylem Planı'nın Fransa Çevre ve Enerji Ajansı tarafından belirlenen kriterlere göre değerlendirmesi

\begin{tabular}{|c|c|c|c|c|c|}
\hline \multicolumn{2}{|c|}{$\begin{array}{c}\text { Aşama } 1 \\
\text { Bölgenin enerji } \\
\text { bakımından mevcut } \\
\text { durum araştırması }\end{array}$} & \multicolumn{2}{|c|}{$\begin{array}{c}\text { Aşama } 2 \\
\text { Bölgenin } \\
\text { potansiyelinin } \\
\text { anlaşılması }\end{array}$} & \multicolumn{2}{|c|}{$\begin{array}{c}\text { Aşama 3 } \\
\text { Strateji ve Eylem } \\
\text { Planlaması }\end{array}$} \\
\hline $\begin{array}{l}\text { Enerji tüketim } \\
\text { ve üretiminin } \\
\text { anlaşııması }\end{array}$ & $\checkmark$ & $\begin{array}{l}\text { Yerel bir öngörü } \\
\text { çalışmasının } \\
\text { yapılması }\end{array}$ & $\checkmark$ & $\begin{array}{l}\text { Uzun vadeli } \\
\text { senaryoların } \\
\text { oluşturulması } \\
(2030,2050)\end{array}$ & $\checkmark$ \\
\hline $\begin{array}{l}\text { Enerji ağları ve } \\
\text { şebekelerin } \\
\text { haritalandırııma } \\
\text { sı }\end{array}$ & $\begin{array}{l}\text { Enerji } \\
\text { Mast } \\
\text { er } \\
\text { Planı } \\
(2018 \rightarrow)\end{array}$ & $\begin{array}{l}\text { Enerji verimliliği } \\
\text { ve yenilenebilir } \\
\text { enerji } \\
\text { potansiyelinin } \\
\text { değerlendirilme } \\
\text { si, ağların ve } \\
\text { sebekelerin } \\
\text { buna göre } \\
\text { haritalandırılma }\end{array}$ & $\begin{array}{l}\text { Enerji } \\
\text { Mast } \\
\text { er } \\
\text { Planı } \\
(2018 \rightarrow)\end{array}$ & $\begin{array}{l}\text { Paydaşların } \\
\text { mevcut ve } \\
\text { potansiyel } \\
\text { katkılarını } \\
\text { içeren kısa ve } \\
\text { orta vadeli } \\
\text { eylem } \\
\text { planlarının } \\
\text { oluşturulması }\end{array}$ & $\checkmark$ \\
\hline \multirow[t]{2}{*}{\begin{tabular}{|l|} 
Yerel \\
yönetimlere \\
düşsen \\
sorumlulukların \\
araştırıması ve \\
kavranması
\end{tabular}} & \multirow[b]{2}{*}{$\checkmark$} & sı & & $\begin{array}{l}\text { Bölgeye özel } \\
\text { göstergelerin } \\
\text { belirlenmesi }\end{array}$ & $\begin{array}{l}\text { Yillık } \\
\text { Enerji } \\
\text { ve } \\
\text { İlim } \\
\text { Rapo } \\
\text { ru } \\
\end{array}$ \\
\hline & & & & $\begin{array}{l}\text { Izleme } \\
\text { sistemlerinin } \\
\text { belirlenmesi }\end{array}$ & $\begin{array}{l}\text { Yillık } \\
\text { Enerji } \\
\text { ve } \\
\text { İlim } \\
\text { Rapo } \\
\text { ru }\end{array}$ \\
\hline
\end{tabular}

\section{Uygulama Alanında En İyi Örnek: Almanya}

Enerji Dönüşümü, Almanya Federal Hükümeti'nin yenilenebilir enerji ve enerji verimliliği öncelikli, düşük karbonlu enerji sistemine geçişi için takip ettiği ulusal bir stratejisidir (Kuittinen ve Velte, 2018) Ulusal ölçekteki bu 
strateji, yerel ve bölgesel otoriteler ile birlikte koordine edilmektedir (Kuittinen ve Velte, 2018). Bu stratejiye göre 2022 yılı sonuna kadar nükleer enerjinin tamamen bitirilmesi, 2050 yılında ise enerji sisteminin büyük ölçüde yenilenebilir kaynaklara bağlı hale gelmesi hedeflenmektedir. Enerji Dönüşümü stratejisinin çerçevesi, 2 anahtar politika belgesi ile düzenlenmiştir. Bunlardan ilki, 2000 yılında yürürlüğe giren Yenilenebilir Enerji Yasası (EEA), diğeri ise Enerji Konsepti Stratejisi'dir (Energiekonzept). 2000 y1lında yürürlüğe giren Yenilenebilir Enerji Yasası, 2018 yılına kadar 2 kez revize edilmiştir. Bu süreçte, federal hükümet, federal bölge yöneticileri ve yerel otoriteler birlikte çalışarak; yol haritalarını belirlemişlerdir.

Literatürdeki birçok çalışma, Almanya'daki yenilenebilir enerji sektörünün büyümesinde, yerel yönetimlerin öncülügünde kurulan kooperatifler aracılı̆̆ıyla yapılan yenilenebilir enerji yatırımlarının önemli yeri olduğunu göstermektedir (Klagge ve Meister, 2018, s.712; Ćetković ve Buzogány, 2016, s.648). Bünyesinde vatandaşları ve özel girişimcileri de barındıran ve yerel yönetimlerin öncülüğünde kurulan bu kooperatifler ya da enerji birlikleri, bölgesel bankalar tarafından fonlanmaktadır (Ćetković ve Buzogány, 2016, s.650). Yerel yönetimler bu noktada banka, vatandaş ya da işletmeler arasındaki iletişim ve koordinasyon görevini üstlenmektedirler. 2012 tarihli veriler, Almanya'da kurulan enerji kapasitesinin yüzde 10'unun kooperatifleşme modeliyle hayat geçirildiğini göstermektedir (DGRV, 2016). Bu modelin yüzde 2'sini yerel yönetimlerin öncülüğünde kurulan kooperatifler oluşturmaktadır.

Almanya'da yayginlaşan kooperatifleşme model ile birlikte 2006 yılında yenilenebilir enerji kooperatifi sayısı 8' den, 2015 yılında 812'ye yükselmiştir (DGRV, 2016). Haziran 2018 itibariyle de Almanya'da aktif olan enerji kooperatifi sayısı 824'e ulaşmıştır. Bu sayı özel girişimle ya da yerel yönetimlerin öncülüğünde kurulan tüm kooperatifleri içermektedir (Klagge ve Meister, 2018, s.714). Son yıllarda, özellikle Almanya'daki teşvik sisteminin değişmesi ile birlikte yıllık bazda kooperatiflerin sayısı azalsa da 2015 yılı itibariyle 240 adet Alman Belediyesi kendi sınırları içerisindeki enerji ihtiyacının çok ötesinde yenilenebilir kaynaklı elektrik üretebilmeyi başarmıştır (Ohlhorst, 2015, s.318). Yerel otoritelerin buradaki temel motivasyonunu, enerji arzında kontrolü devam ettirmek, karlılık, istihdam artışı, arz güvenliği, artan enerji fiyatlarından zarar görmemek, oluşturmaktadır (Ohlhorst, 2015, s. 312). 


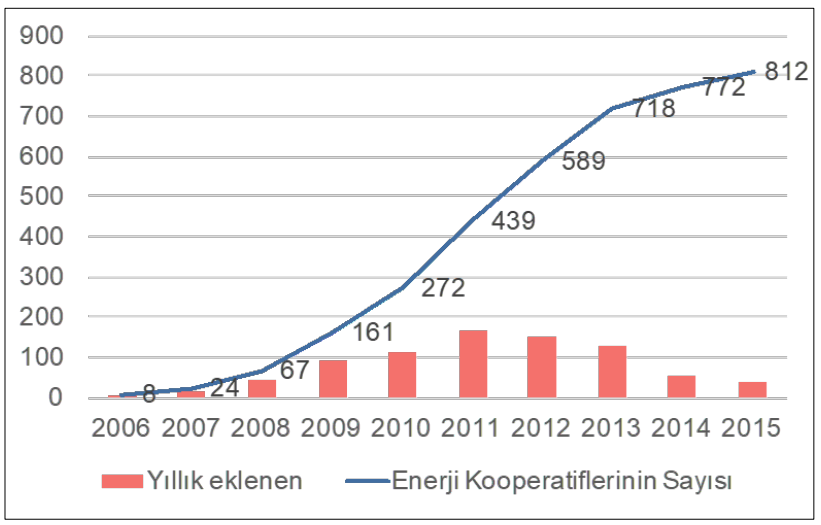

Şekil 3. Almanya'da her yıl Kurulan Enerji Kooperatifleri Sayısı

Kaynak: DGRV, 2016

Yerel otoriteler ve/veya kamu enstitüleri ve bölgesel bankalar işbirliğinde 2015 yılına kadar kurulmuş olan kooperatiflerin ortalama pay sahipliği Şekil 4 kapsamında gösterilmektedir. Bu modelde kurulmuş yenilenebilir enerji uygulamalarında yerel yönetimlerin ortalama payı yukarıda da belirtildiği gibi yüzde 2 civarındadır.

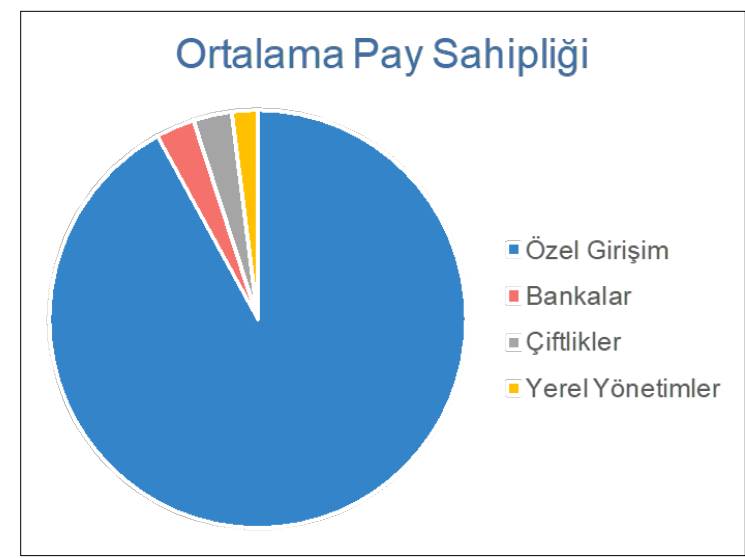

Şekil 4. Enerji Kooperatiflerinin Ortalama Pay Sahipliği

Kaynak: DGRV, 2016

Sonuç olarak Fransa'da kapsamlı planlama, Almanya'da ise kooperatif modeli yerel yönetimlerin yenilenebilir enerji alanında başarılı örnekleri olarak gösterilebilir. Bu uygulamaların önemi bir sonraki bölümü oluşturan 
Türkiye örneği üzerinden tekrar ele alınacak ve Türk yerel yönetim sistemindeki yenilenebilir enerji kapasitesinin artırılması bağlamında derinlemesine tartışılacaktır.

\section{Türkiye' de Yenilenebilir Enerji Alanı}

Türkiye uzun yıllardır enerjisinin büyük bir kısmını dışarıdan ithal eden bir ülkedir. Dünya Bankası'nın 2015 tarihli verilerine göre Türkiye'de enerjinin dışa bağımlılık oranı yüzde 75 seviyelerindedir. Sanayileşme sürecinin hızlandığı ve kırdan kente göçün görünür hale geldiği 1960'll yıllar itibariyle Türkiye'de enerjinin dışa bağımlılı̆̆ında ciddi bir artış gözlemlenmiştir. Neo-liberal politikaların etkisi ile birlikte Türkiye'nin enerjide dışa bağımlılık seviyesi 1980'li yıllarda yüzde 46 seviyelerine ulaşmış; 2000'li yıllara gelindiğinde ise Türkiye artık enerjisinin neredeyse üçte birini dışarıdan ithal eden bir ülke konumuna gelmiştir (Dünya Bankası, 2015).

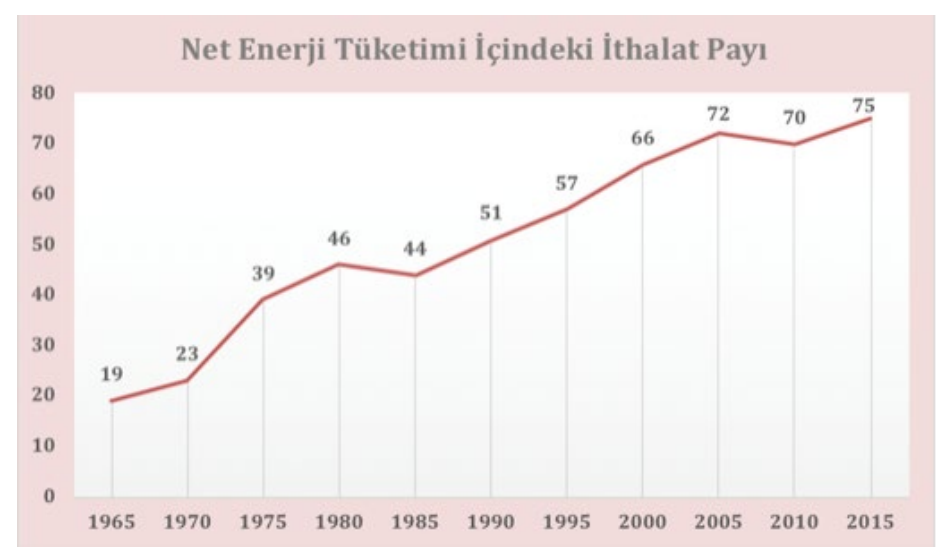

Şekil 5. Dünya Bankası Verilerine Göre Türkiye' nin Net Enerji Tüketimi İçindeki İthalat Pay1

Yukarıdaki şekilde de görüldüğü üzere Türkiye'nin enerjide dışa bağımlıllğının gelecek dönemlerde artabileceği varsayımı doğrultusunda, yerli ve yenilenebilir enerji kaynaklarının kullanılmasını teşvik etmek kaçınılmaz bir hal almaktadır. Bununla beraber yenilenebilir enerji kaynaklarının etkin ve verimli bir şekilde kullanılması da özellikle Türkiye gibi enerjide dışa bağımlı ülkeler açısından son derece önemlidir. Yenilenebilir enerji kaynaklarının etkin ve verimli kullanımı, dışa bağımlılığın azaltılmasının yanı sıra; 
enerjide arz güvenliğinin sağlanması, çevresel değerlerin korunması ve çevreye verilen zararın azaltılması, hizmetlerin daha tasarruflu ve az maliyetli bir şekilde sunulmasına olanak sağlayacaktır.

Türkiye, jeopolitik yapısı, dört mevsim iklim ve yer şekilleri özellikleri ile zengin bir yenilenebilir enerji kaynak potansiyeline sahip bir ülkedir. Sahip olduğu bu zengin kaynaklar, Türkiye'nin mevcut enerji ihtiyacını karşılayabilecek ve enerjide dışa bağımlılığı azaltabilecek düzeydedir (Yılmaz, 2012, s.52). Türkiye'nin de üye ülkeler arasında yer aldığı 1 Uluslararası Yenilenebilir Enerji Ajansı'nın (IRENA) 2017 yılı Yenilenebilir Enerji İstatistikleri Raporu'na göre ülkemiz elektrik üretiminde yenilenebilir enerji kaynaklarının kullanımı açısından üye ülkeler arasında 13. sırada bulunmaktadır (IRENA, 2017). Türkiye'nin 2023 hedefleri göz önünde bulundurulduğunda da yenilenebilir enerji kaynaklarının elektrik üretimindeki payının en az yüzde 30 seviyelerine çıkarılmasının hedeflendiği görülmektedir. Bu doğrultuda yapılan çalışmalar incelendiğinde, özellikle 2001 yılından itibaren çıkarılan yasal düzenlemeler ile enerji sektöründe yeniden yapılandırma sürecine önem verildiği; bu alanda yenilenebilir enerji kaynaklarından elektrik üretimi ve üretilen enerjinin verimli ve etkin bir şekilde kullanılması adına teşvik mekanizmalarının geliştirildiği görülmektedir. 2000'li yıllar öncesinde 5.,6. ve 7. Beş Yıllık Kalkınma Planları kapsamında ele alınan yenilenebilir enerji alanına yönelik hedef ve eylemler, aşağıda oluşturulan Tablo 3'te de görüldüğü üzere, 2000'li yıllar itibariyle çeşitlilik kazanmış, yasal düzenlemeler ve bu alana yönelik teşvik mekanizmaları geliştirilmiştir.

Yukarıdaki Tablo 3'te de görüldüğü üzere, Türkiye'de 2000 yılı itibariyle yenilenebilir enerji alanına yönelik yapılan düzenlemelerin ana hedefi, enerjide dışa bağımlılı̆̆ın azaltılarak, yerli kaynaklarla üretimi desteklemektir. 2001 yılından günümüze kadar ulusal ölçekte yapılan yasal düzenlemeler incelendiğinde bu düzenlemelerin, merkezi yönetimin etkisinde kaldığı ve özellikle bakanlıklar düzeyinde ele alındığı görülmektedir. Ancak düzenlemeler ayrıntılı incelendiği zaman bu düzenlemelerin, merkeziyetçi anlayıştan farklı bir bakışı yansıttığı, çok disiplinli çalışmalar gerektiren konuları barındırdığı, çok ortaklı ve çok kademelenmeli yapıları oluşturduğu dikkati çekmektedir. Bu bağlamda Türkiye'de yenilenebilir enerji alanında yapılan yasal düzenlemelere göre öngörülen faaliyetlerin uygulamaya geçirilmesi ve tedbirlerin alınmasında tek başına merkezi yönetim kuruluşları ve onların taşra birimlerinin yeterli olmadığı açıktır. 
Tablo 3. 2000 Yılı Sonrası Yenilenebilir Enerji Alanına Yönelik Türkiye'de Yapılan

Yasal Düzenlemeler ve Teşvik Mekanizmaları

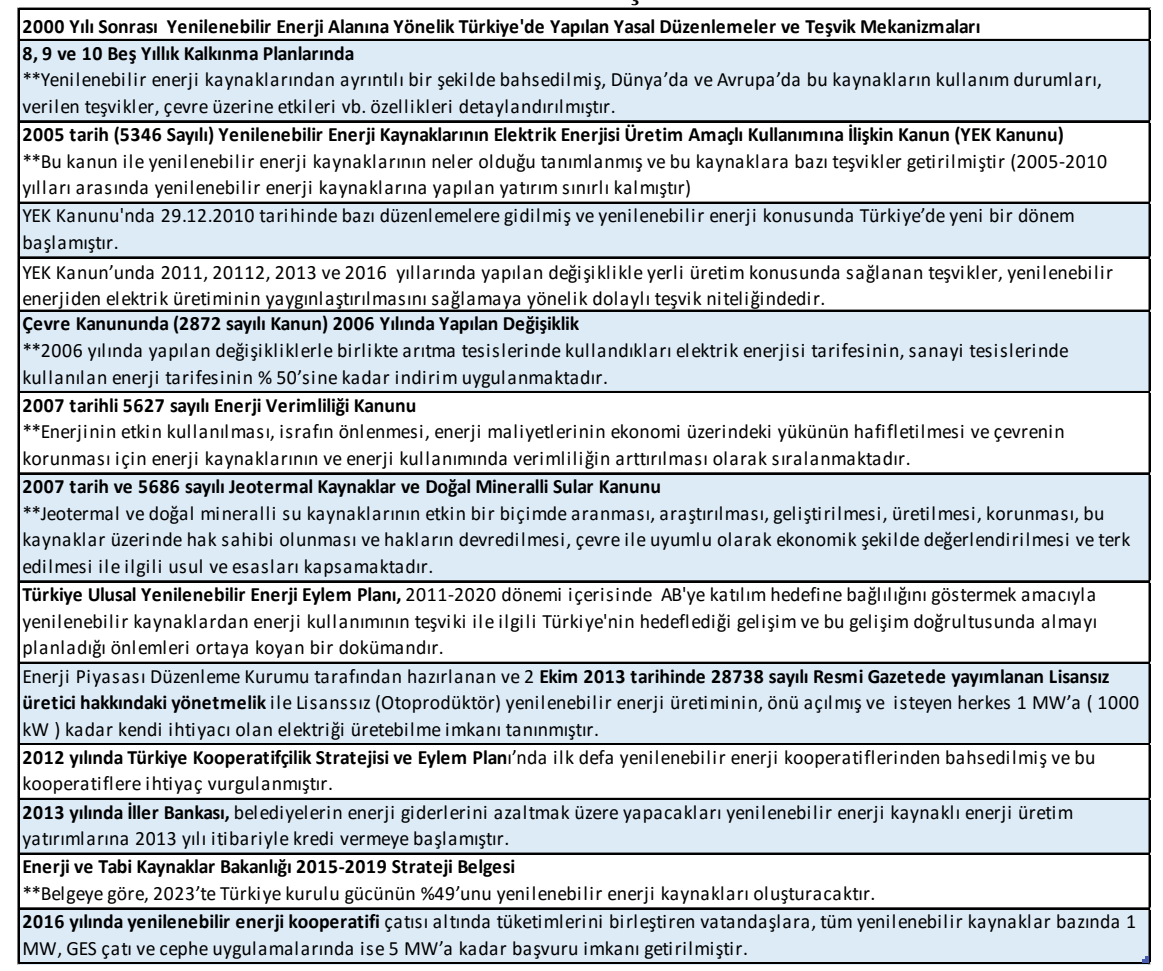

Türkiye'de bugün nüfusun neredeyse yüzde 93'ünün kent yönetimi olan belediye sınırları içerisinde, bunun yüzde 77,6'sının büyükşehir belediyelerinde; geri kalan yüzde 22,34'ünün ise diğer belediye sınırları içerisinde yaşadığı göz önünde bulundurulduğunda; enerji ihtiyacının karşılanmasında, enerji verimliliğinin sağlanmasında, yerelden merkeze doğru ivmelenecek enerji politikalarının hayata geçirilmesinde, merkezi yönetim kadar yerel yönetimlere de büyük ödevler, görevler ve sorumluluklar düşmektedir. Uluslararası arenada da enerji üretiminin ve verimliliğinin yerel yönetimlerin sorumluluğunda olması çok sık rastlanan bir olgudur. Bir önceki bölümde tartsşılan gelişmiş ülke örnekleri göz önünde bulundurulduğunda, yenilenebilir enerji alanında merkezi yönetimin dışında yerel yönetimlerin, yenilenebilir enerji yatırımlarının büyük çoğunluğunu ellerinde tuttukları, merkezi olmayan enerji altyapılarının kontrolünü sağladıkları ve 2000'li yıllar sonrasında da yenilenebilir enerji alanında özel imtiyazları sona erdirerek yerel enerji altyapılarını devralmaya başladıkları görülmüştür. Türkiye'de ise 5216 sayılı Büyükşehir Belediye Kanunu, 5393 sayılı Belediye 
Kanunu ve 5302 sayılı İl Özel İdaresi Kanunu çerçevesinde görev alanları tanımlanan yerel yönetimlerin enerji alanına yönelik yürütmüş oldukları birçok politika ve faaliyet alanları, yörenin stratejik öncelik ve hedefleri göz ardı edilerek hazırlanmış; bu politika ve faaliyet alanları genellikle kurumiçi performans göstergelerinin iyileştirilmesinden öteye gidemediği hipotezi doğrulanarak, bulgular ölçeğinde yansitılmaya çalışılacaktır. Bu bulguya, çalışma kapsamında yapılan derinlemesine araştırma yönetimi sonucunda ulaşılmıştır. Çalışma kapsamında derinlemesine araştırma yönetiminden yararlanılarak; Türkiye'de nüfusun ve enerji ihtiyacının büyük bir kısmına ev sahipliği yapan 30 büyükşehir belediyesinin enerji politika ve faaliyet alanları, (1) 2014-2019 yılları arasını kapsayan stratejik planları, (2) 2014-2019 yılları arasında her yıl düzenli aralıklarla yayımlanan performans programları, (3) 2014-2019 yılları arasında her yıl düzenli aralıklarla yayımlanan faaliyet raporları üzerinden incelenmiştir. Çalışmanın bir sonraki bölümünde bu bağlamda yapılan araştırma bulgularına yer verilecektir.

\section{Büyüksşehir Belediyesinin Yenilenebilir Enerji Politikaları}

Çalışmanın bu bölümünde Türkiye'de nüfusun neredeyse yüzde 80'nini barındıran 30 büyükşehir belediyesinin yenilenebilir enerji alanına yönelik yürütmüş oldukları birçok politika ve faaliyet alanları incelenecek ve elde edilen bulgular yenilenebilir enerji alanı üzerinden değerlendirilecektir. Çalışma kapsamında 30 büyükşehir belediyesinin seçilme nedeni ise Türkiye nüfusunun önemli bir bölümüne ev sahipliği yapmasından kaynaklıdır. Çalışmada ayrıntılı incelenen büyükşehir belediyelerinin listelerine aşağ1daki Tablo 4 kapsamında yer verilmiştir.

Tablo 4. Çalışma kapsamında araştırılan büyükşehir belediyeleri

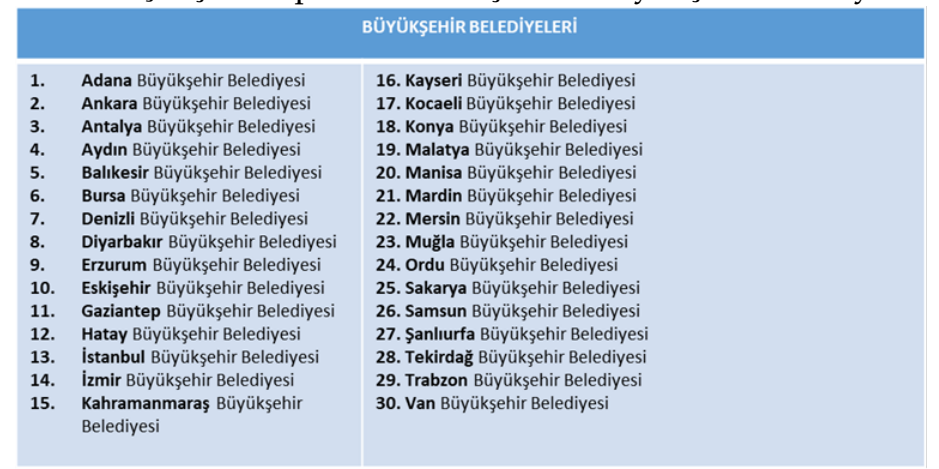


30 Büyükşehir Belediyesinin 2014-2019 yılları arasını kapsayan stratejik planları, aynı yılları kapsayan ve her yıl düzenli aralıklarla yayımlanan performans programları ve faaliyet raporlarında yenilenebilir enerji alanına yönelik politika değerlendirmelerine ve bulgularına geçmeden önce; 30 ilde türlerine göre yenilenebilir enerji santrallerinin mevcut durumuna yer vermekte fayda vardır. Türkiye'nin Enerji Atlası 2018 verilerine göre (Şekil 6) 30 ilde yenilenebilir enerji santral türlerinden en büyük orana, güneş enerjisi santralleri sahiptir (Türkiye'nin Enerji Atlası, 2018)

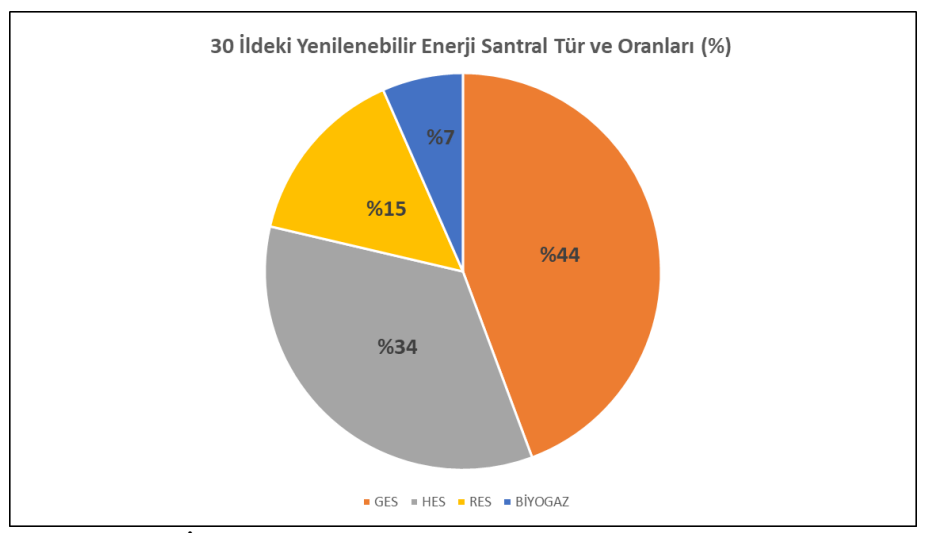

Şekil 6. 30 İlde Türlerine Göre Yenilenebilir Enerji Santralleri

Kaynak: Türkiye'nin Enerji Atlası, 2018

30 ilde yüzde 44 gibi en büyük orana sahip olan güneş enerjisi santrallerini, yüzde 34 ile hidroelektrik santralleri, yüzde 15 ile rüzgâr enerjisi santralleri ve yüzde 7 ile biyogaz santralleri takip etmektedir.

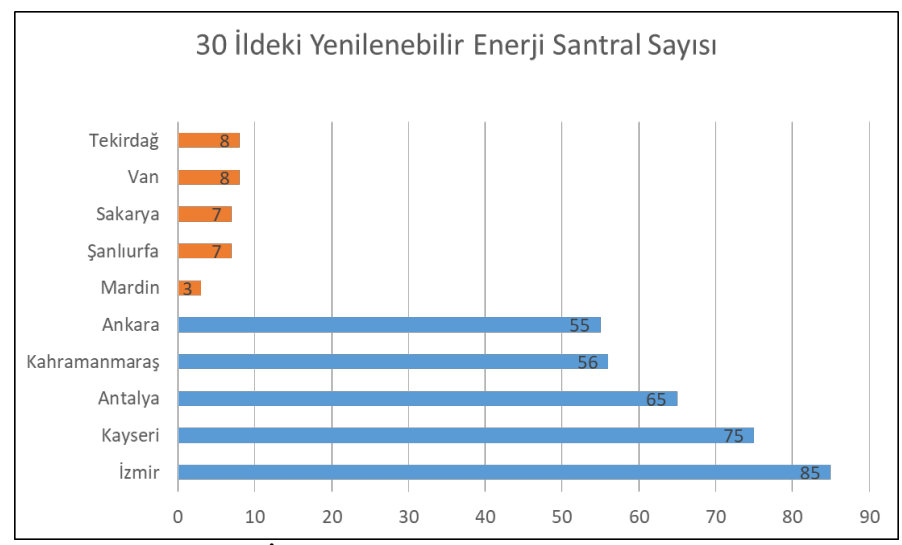

Şekil 7. 30 İlde Yenilenebilir Enerji Santral Sayısı

Kaynak: Türkiye'nin Enerji Atlası, 2018 
Türkiye'nin Enerji Atlası 2018 verilerine göre (Şekil 7) 30 il içerisinde en çok yenilenebilir enerji santral sayısına sahip olan ilk beş il sırasıyla; İzmir (85 santral), Kayseri (75 santral), Antalya (65 santral), Kahramanmaraş (56 santral) ve Ankara'dır. (55 santral). En az yenilenebilir enerji santral sayısına sahip olan iller ise; Mardin ( 3 santral), Şanlıurfa (7 santral), Sakarya (7 santral), Van (8 santral) ve Tekirdağ'dır(8 santral).

Büyükşehir belediye işletmesi bünyesinde işletilen yenilenebilir enerji santrallerine bakıldığında ise yine Türkiye'nin Enerji Atlası 2018 verilerine göre 11 büyükşehir belediyesi işletmesinde herhangi bir yenilenebilir enerji santraline rastlanmadığı sonucuna ulaşılmıştır. 9 büyükşehir belediyesi işletmesinde 1 adet, 4 büyükşehir belediyesi işletmesinde 2 adet, 3 büyükşsehir belediyesi işletmesinde 3 adet, 1 büyükşehir belediyesi işletmesinde 4 adet, 2 büyükşehir belediyesi işletmesinde ise toplam 6 adet yenilenebilir enerji santralleri bulunmaktadır.
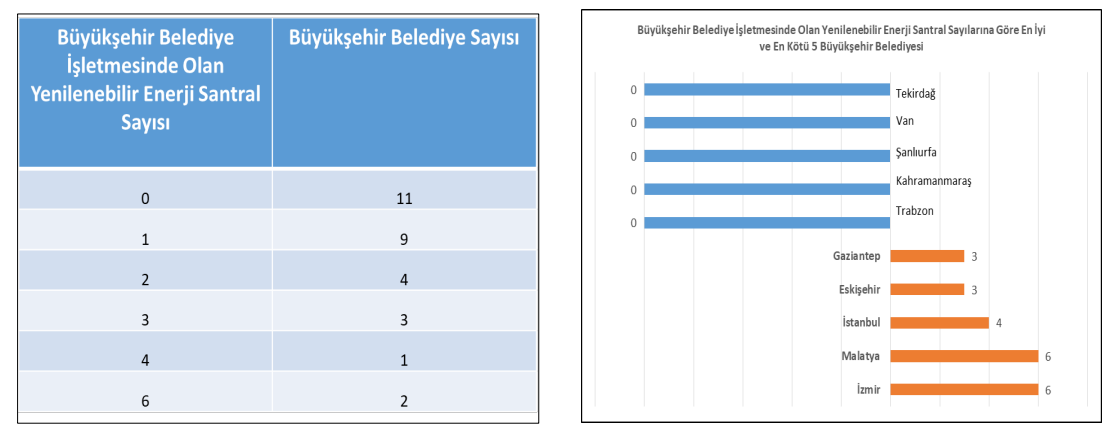

Şekil 8. Büyükşehir Belediye İşletmesinde Olan Yenilenebilir Enerji Santral Sayısı Kaynak: Türkiye'nin Enerji Atlası, 2018

Büyükşehir belediye işletmesinde olan yenilenebilir enerji santral say1ları göz önünde bulundurulduğunda; belediye bünyesinde işletilen ve en çok yenilenebilir enerji santrallerine sahip olan il, İzmir ve Malatya'dır (6'şar adet santral ). İzmir ve Malatya'yı sırasıyla İstanbul (4 adet), Eskişehir ve Gaziantep (3'er adet) izlemektedir. Büyükşehir belediye işletmesinde yenilenebilir enerji santraline sahip olmayan iller ise Tekirdağ, Van, Şanlıurfa, Kahramanmaraş ve Trabzon'dur. Büyükşehir belediye bünyesinde işletilen yenilenebilir enerji santral türlerine bakıldığında ise en büyük oran yüzde 59,52 ile güneş enerjisi santralleridir. Bunu yüzde 26 ile biyogaz, yüzde 11,90 ile hidroelektrik santralleri ve yüzde 2,38 ile rüzgar enerjisi santralleri izlemektedir. 


\section{Büyükşehir Belediye İşletmesinde Olan Yenilenebilir}

Enerji Santral Tür ve Oranları

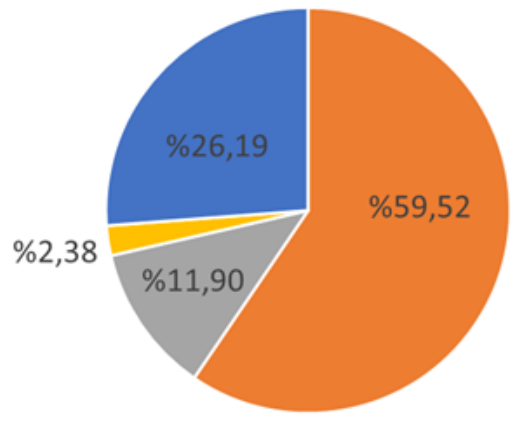

= GES = HES = RES = BIYOGAZ

Şekil 9. Büyükşehir Belediye İşletmesinde Olan Yenilenebilir Enerji Santral Tür ve Oranları

Kaynak: Türkiye'nin Enerji Atlası, 2018

30 ilin yenilenebilir enerji alanına yönelik mevcut durumlarının incelenmesinin ardından, 30 büyükşehir belediyesinin stratejik planlarında yenilenebilir enerji alanına yönelik hedef ve faaliyetleri hangi stratejik amaç başlığı altında ele alındığına bakılacak olursa; 30 büyükşehir belediyesinin 21 tanesinin yenilenebilir enerji alanına yönelik hedef ve faaliyetlerini "çevre" başlığı altında tartıştı̆̆ görülmüştür. 21 büyükşehir belediyesi dışında Antalya ve Samsun büyükşehir belediyeleri, "kentsel yaşam kalitesi", Şanl1urfa Büyükşehir Belediyesi "kurumsal gelişim” ve Van Büyükşehir Belediyesi "enerji" başlığı altında yenilenebilir enerji alanına yönelik hedef ve faaliyetlerini belirledikleri gözlemlenmiştir. Ordu, Tekirdağ ve Denizli büyükşehir belediyelerinin ise stratejik planlarında yenilenebilir enerji alanlarına hiç yer vermedikleri görülmüştür.

Ordu, Tekirdağ ve Denizli büyükşehir belediyeleri hariç 27 büyükşehir belediyesinin stratejik planları ve faaliyet raporlarında, yenilenebilir enerji alanlarına yönelik temel faaliyet alanları incelendiğinde ise yenilenebilir enerji alanının, birden çok faaliyet başlığı altında değerlendirildiği gözlemlenmiştir. Bu başlıklar aşağıda belirtildiği şekilde ele alınmaktadır;

- Yenilenebilir enerji alanına yönelik proje geliştirmek ve yürütmek;

- Plan ve projelerde GES, HES ve RES için yatırım alanlarının belirlenmesi;

- GES, HES ve RES kurmak ve işletmek; 
- Güneş enerjisiyle merada hayvan içme tesisi kurulumu;

- Katı atıkların geri dönüşümü ve temiz enerji üretimi;

- Yenilenebilir enerji alanında bilgilendirme ve seminer düzenlenmesi;

- Belediye hizmet binalarının elektrik ve yakıt giderlerinin karşılanmasi;

- Aydınlatma çalışmalarının yapılması (güneş enerjisi ve güneş durakları);

- Aydınlatma çalışmalarının yapılması (led ampül);

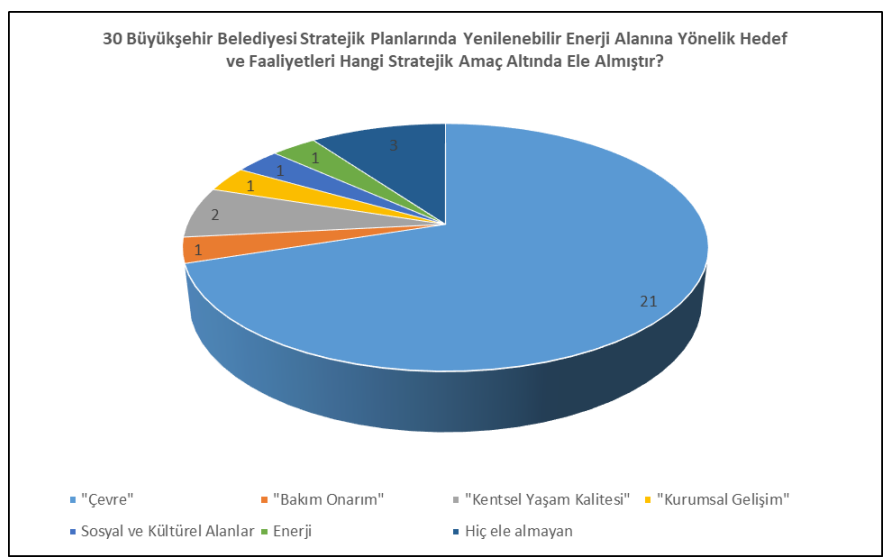

Şekil 10. 30 Büyükşehir Belediyesi Stratejik Planlarında Yenilenebilir Enerji Alanına Yönelik Hedef ve Faaliyetleri Hangi Stratejik Amaç Altında Ele Almıştır?

Belediyeler planlarında, birden çok başlığ 1 yenilenebilir enerji alanlarına yönelik temel faaliyet alanlarında yer vermişlerdir. Bu başlıklar içerisinde yenilenebilir enerji alanına stratejik planlarda en çok yer verilen faaliyet alanı, "belediye hizmet binalarının elektrik ve yakıt giderlerinin karşılanması" olarak belirlenmiştir. Bu faaliyet alanı 12 büyükşehir belediyesinin stratejik planlarına ve faaliyet raporlarına yansıtılmıştır. Bu faaliyet başlığını, "GES, HES ve RES kurmak ve işletmek", "aydınlatma çalışmalarını yapmak" ve "yenilenebilir enerji alanına yönelik proje geliştirmek ve yürütmek" başlıkları takip etmektedir. 


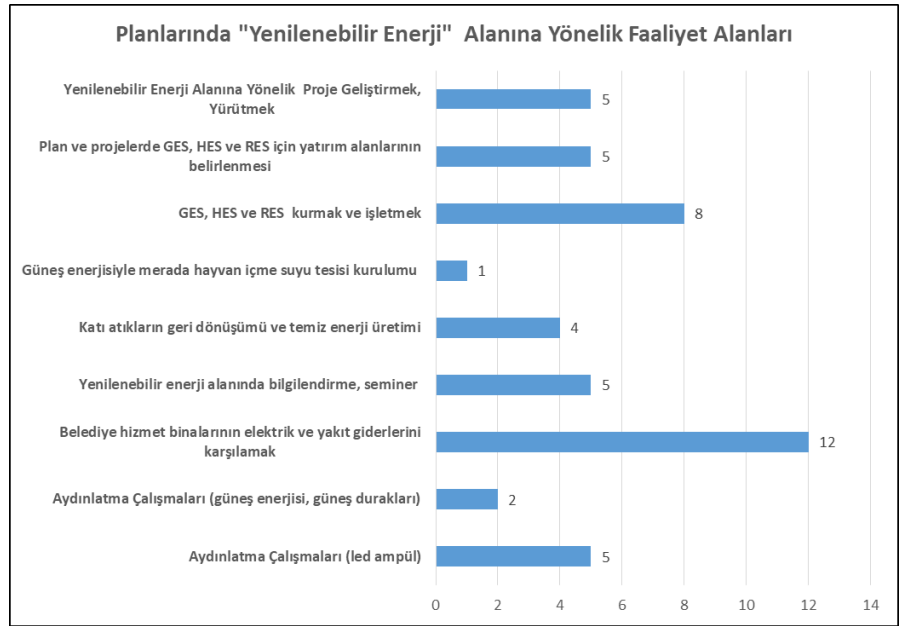

Şekil 11. Büyükşehir Belediyelerin Yenilenebilir Enerji Alanlarına Yönelik Temel Faaliyet Alanları

Yine belediyeler ölçeğinde, (Tablo 5) yenilenebilir enerjinin faaliyet alanlarının hangi belediyeler tarafından nasıl ele alındığına bakacak olursak; Ankara, Balıkesir, İstanbul, Şanlıurfa, Adana, Kocaeli, Bursa, Sakarya, Trabzon, Mersin, Mardin ve Samsun büyükşehir belediyeleri yenilenebilir enerjiyi, "belediye hizmet binalarının elektrik ve yakıt giderlerinin karşılanması" faaliyeti altında tartışmıslardır. Antalya, İzmir, Malatya, Manisa, Diyarbakır, Eskişehir, Muğla ve Van büyükşehir belediyeleri ise yenilenebilir enerjiyi, "GES, HES ve RES kurmak ve işletmek" faaliyeti altında tartışışlardır.

Tablo 5. Büyükşehir Belediyelerin Yenilenebilir Enerji Alanlarına Yönelik Temel Faaliyet Alanları

\begin{tabular}{|c|c|}
\hline $\begin{array}{l}\text { Büyükşehir Belediyelerin Yenilenebilir } \\
\text { Enerji Alanlarına Yönelik Temel Faaliyet } \\
\text { Alanları }\end{array}$ & Büyükşehir Belediyeleri \\
\hline Aydınlatma Çalışmaları (led ampül) & Adana, İstanbul, Ballkesir, Kahramanmaraş, Kocaeli, \\
\hline Aydınlatma Çalıșmaları (güneş enerjisi, güneş durakları) & Kayseri, Hatay \\
\hline Belediye hizmet binalarının elektrik ve yakıt giderlerini karşılamak & $\begin{array}{l}\text { Ankara, Ballkesir, Istanbul, Sanllurfa, Adana, Kocaeli, Bursa, Sakarya, } \\
\text { Trabzon, Mersin, Mardin, Samsun }\end{array}$ \\
\hline Yenilenebilir enerji alannnda bilgilendirme, seminer & Gaziantep, Antalya, Erzurum, Trabzon, Samsun \\
\hline Katı atıkların geri dönüşümü ve temiz enerji üretimi & Eskişehir, Bursa, Hatay, Sakarya \\
\hline Güneş enerjisiyle merada hayvan içme suyu tesisi kurulumu & Gaziantep \\
\hline GES, HES ve RES kurmak ve işletmek & Antalya, Izmir, Malatya, Manisa, Diyarbakir, Eskişehir, Muğla, Van, \\
\hline Plan ve projelerde GES, HES ve RES için yatııım alanlarının belirlenmesi & Hatay, Konya, Diyarbakır, Kahramanmaraş, Mardin \\
\hline Yenilenebilir Enerji Alanına Yönelik Proje Geliştirmek, Yü & izmir, Eskișehir, Erzurum, Gaziantep, Samsun \\
\hline
\end{tabular}


Bu kapsamda çalışmamızın başında belirttiğimiz, "yerel yönetimlerin enerji alanına yönelik yürütmüş oldukları birçok politika ve faaliyet alanlarının, genellikle kurumiçi performans göstergelerinin iyileştirilmesinden öteye gidemediğii" hipotezi bu bulgular ışığında doğrulanmıştır.

Çalışma kapsamında araştırılan bir diğer başlık, büyükş̧ehir belediyelerinin yıllık performans programlarına göre yenilenebilir enerji alanına aktarılan paylarıdır. Bu kapsamda Ordu, Tekirdağ ve Denizli büyükşehir belediyeleri hariç 27 büyükşehir belediyesinin 2014-2019 yılları arasını kapsayan ve yıllık olarak yayımlanan performans programları detaylı olarak incelenmiştir. Yapılan araştırmaya göre 27 büyükşehir belediyesinin yüzde 63,3'ünün, yenilenebilir enerji alanına yıllık aktardıkları ortalama payın yüzde 0,01-0,1 arasında olduğu görülmektedir. 27 büyükşehir belediyesinin yüzde 10'nun bu alana yönelik hiç kaynak ayırmadığı; yüzde 13'ünün ise yenilenebilir enerji alanına yönelik yüzde 1-2 arasında kaynak ayırdığı dikkati çekmektedir.

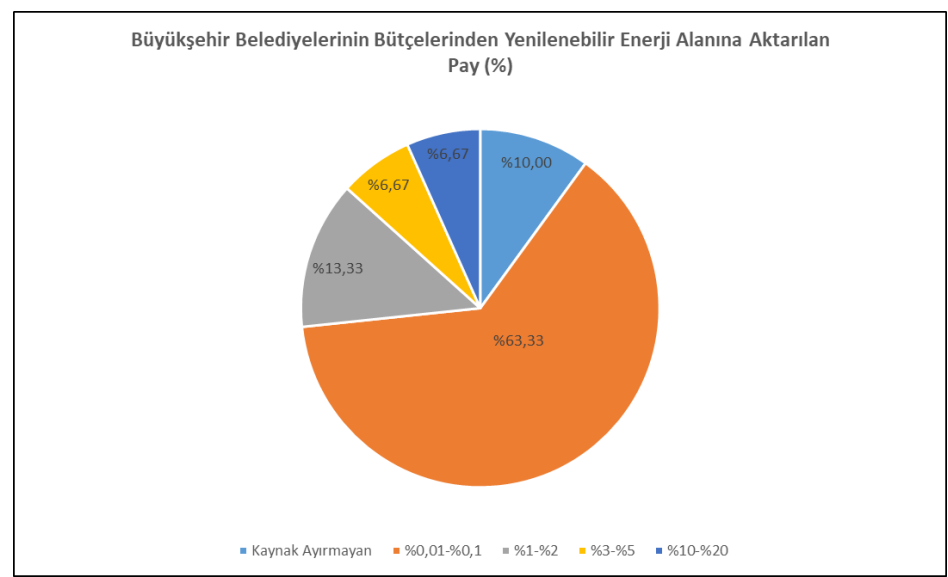

Şekil 13. Büyükşehir Belediyelerinin Yıllık Performans Programlarına Göre Yenilenebilir Enerji Alanına Aktarılan Pay (\%)

Son olarak 27 büyükşehir belediyesinin stratejik planları ve faaliyet raporlarında yenilenebilir enerji alanına yönelik performans göstergeleri incelendiğinde, göstergelerinde kurumiçi performans göstergelerinin iyileştirilmesinden öteye gidemediği" hipotezinin bir kez daha doğrulandığı görülmektedir (Tablo 6). Yenilenebilir enerji alanına yönelik performans göstergelerinden "belediyelerin birimlerine tedarik edilen elektrik enerjisi", kurulan aydınlatma sistemi sayısı" gibi göstergelerin ölçülebilir olmaktan öte kurumiçi performansı yansıtan göstergeler olduğu dikkati çekmektedir. 
Tablo 6. Büyükşehir Belediyelerinin Yenilenebilir Enerji Alanını Yönelik Göstergeler

\begin{tabular}{|l|c|}
\hline \multicolumn{1}{|c|}{ Göstergeler } & Ölçüm \\
\hline Yenilenebilir enerji kaynakları ile çalışan sistem sayısı & (adet/yıl) \\
\hline Kurulan aydınlatma sistemi sayısı & (adet/yıl) \\
\hline Temin edilen elektrik miktarı & (kwh/ay) \\
\hline Bakım onarımı yapılan tesis, aydınlatma sayıs & (adet/yıl) \\
\hline Hazırlanan aydınlatma proje çalışması & (adet/yıl) \\
\hline Belediyemiz birimlerine tedarik edilen elektrik enerjisi & (kw/h \\
\hline Yıl içinde gerçekleştirilecek faaliyet ve proje sayısı & (adet/yıl) \\
\hline Yenilenebilir enerji kaynaklarından yararlanılarak örnek uygulama yapılacak park sayısı & (adet/yıl) \\
\hline Enerji verimliliği ve karbon salınımı ile ilgili yapılacak çalışma sayısı & (adet/yıl) \\
\hline Enerji verimliliği ile ilgili düzenlenecek eğitim sayısı & (adet/yıl) \\
\hline
\end{tabular}

Çalışma kapsamında 30 büyükşehir belediyesinin, 2014-2019 yılları arasını kapsayan stratejik planları, aynı yılları kapsayan ve her yıl düzenli aralıklarla yayımlanan performans programları ve faaliyet raporlarında yenilenebilir enerji alanına yönelik yapılan çalışmaları incelendiğinde, i) bazı büyükşehir belediyelerinin bu alana yönelik hiçbir faaliyette bulunmadıkları, ii)belediyelerin yenilenebilir enerji alanına yönelik gerçek anlamda bir faaliyet geliştirmedikleri, iii) yenilenebilir enerji alanına yönelik yürütmüş oldukları birçok politika ve faaliyet alanlarını, yörenin stratejik öncelik ve hedeflerini göz ardı ederek oluşturdukları, iv) bu alana yönelik faaliyetlerin ise genellikle kurumiçi performans göstergelerinin iyileştirilmesinden öteye gidemediği gözlemlenmiştir. Çalışmanın sonucunda yenilenebilir enerji alanında önemli bir yere sahip olan yerel yönetimlerin Türkiye'de ne yazık ki gerekli görev ve sorumlulukları üstlenmediği dikkati çekmektedir.

\section{Sonuç Yerine; Yenilenebilir Enerji Alanında Türkiye'de Yerel Yöne- timler İçin İki Aşamalı Yol Haritası}

Türkiye'de yerel yönetimlere, enerjide dışa bağımlılı̆̆ın azaltılması ve enerji arz ve taleplerinin dengelenmesi bağlamında büyük görevler ve sorumluluklar düşmektedir. Bu bağlamda bir önceki bölümde tartışılan Fransa ve Almanya yerel yönetim örnekleri üzerinden güçlü bir enerji potansiyeline sahip olan Türkiye'deki yerel yönetimler için iki aşamalı bir yol haritası önerilebilir.

Belirtilen bu yol haritalarından ilkini, kapsayıcı ve sürekli güncellenen bir sürdürülebilir enerji aksiyon planı oluşturmaktadır. Bir önceki kısımda planlama sürecinde başarılı uygulama örneği kapsamında tartışılan Fransa'daki yerel yönetimlerin yaptıkları yenilenebilir enerji eylem planları, Türkiye'deki yerel yönetimler açısından yol gösterici olabilir. 
Türkiye'deki yerel yönetimler aslında yenilenebilir enerji eylem planlarının hazırlanması sürecine uzak değildirler. Avrupa Komisyonu'nca 2014 yılında yürürlüğe giren ve sürdürülebilir enerji politikalarını destekleyen Başkanlar Sözleşmesi'ne Türkiye'den de 2 büyükşshir belediyesi ve 6 ilçe belediyesi taraf olmuştur. Bu belediyeler; İzmir Büyükşehir Belediyesi, Gaziantep Büyükşehir Belediyesi, Bornova İlçe Belediyesi, Seferihisar İlçe Belediyesi, Tepebaşı İlçe Belediyesi, Kadıköy İlçe Belediyesi, Bursa/Nilüfer İlçe Belediyesi ve Çankaya İlçe Belediyesidir. Başkanlar Sözleşmesi uyarınca Türkiye'de sözleşmeyi imzalayan belediyeler 2020 yılı için sera gazı salınımlarını ortalama yüzde 20 azaltmayı ve bu hedef için uygulayacağı "Sürdürülebilir Enerji Eylem Planlarını" Avrupa Birliğine sunmayı taahhüt etmişlerdir. Bu taahhüt gereği 2015 yılı itibariyle yukarıda belirtilen büyükşehir ve ilçe belediyeleri, bu planlarını özel bir şirket eliyle hazırlamışlar ve Birliğe sunmuşlardır. Ancak bu planlar detaylı olarak incelendiğinde, planların yenilenebilir enerji alanına yönelik literatür taramasından öteye gitmediği görülmektedir. Birçoğu benzer başlıklar altında tartışılan planlar, yenilenebilir enerji alanından öte iklim değişikliğinin önemine vurgu yapmıslardır. Ayrıca planlarda yenilenebilir enerji alanında geleceğe yönelik tahminlerin ötesinde daha çok mevcut durumu yansıtan başlıklara yer verilmiştir. 2 büyükşehir belediyesi ve 6 ilçe belediyesi tarafından özel bir şirket eliyle hazırlanan sürdürülebilir enerji planlarında ele alınan başlıklar şu şekildedir $^{1}$ :

- İklim Değişikliği Nedir?

- Uluslararası ve Yerel Yönetimlerde İklim Değişikliği Anlaşmaları

- Belediye Sinırlarında Mevcut Yenilenebilir Enerji Durumu

- Bölgenin ve Belediye Sinırlarında Yapı Stoku

- Belediye Sinırlarında Sera Gazı Emisyon Envanteri

- Belediye Tarafından Düzenlenen Sürdürülebilir Enerji Eylem Planı Aşamaları ve Bu Alanda Düzenlenen Çalıştaylar

- İdari sınırlar dışında ithal edilen enerjinin azaltılması ihtimalinin araştırılması ve projelerinin belirlenmesi;

- Yenilenebilir enerji alanına yönelik mevcut durumu içeren yerel ve bölgesel ölçekte haritalama.

- Yapılması planlanan ve gelecekte öngörülen projeler kapsamında yerel ve bölgesel ölçekte haritalama.

\footnotetext{
${ }^{1}$ Ayrıntılı bilgi için bkz: İzmir Büyükşehir Belediyesi Sürdürülebilir Enerji Eylem Planı, 2016.
} 
Türkiye içinde güçlü bir potansiyele sahip olan yerel yönetimlerin, Fransa örneğinden de görüldügü üzere, yenilenebilir enerji alanına yönelik literatür taramasının ötesinde; i)enerji arzı, tüketimi ve ağlarının analiz edilmesini ve haritalandırılmasını, ii) enerji karmasının planlanmasını ve fizibilite çalışmalarının yapılmasını, iii) enerji verimliliği potansiyelinin analiz edilmesini, iv) enerji projeksiyonlarının (kısa, orta ve uzun vade) ve hedeflerin belirlenmesini, v) ulusal hedefleri gözeten, teknik, finansal ve ekonomik faktörleri kapsayan ve tüm paydaşları içeren kapsamlı bir yenilenebilir enerji eylem planlarına yer vermesi gerekmektedir.

Türkiye'deki yerel yönetimler için ikinci yol haritasını ise bir önceki bölümde Almanya örneği üzerinden tartışlan ve yerel yönetimler ortakl1ğında kurulan yenilenebilir enerji kooperatifleri oluşturmaktadır. Yerel yönetimler ortaklığında kurulan yenilenebilir enerji kooperatifleri uygulamasına köklü bir kooperatifçilik geçmişine sahip olan ülkemiz yabancı değildir. 2012 yılı itibariyle Türkiye'de yenilenebilir enerji kooperatiflerinin oluşturulması için yasal düzenlemeler de yapılmıştır. Bunlardan ilki, 2012 yılında Türkiye Kooperatifçilik Stratejisi ve Eylem Planı'nında yenilenebilir enerji kooperatiflerine yönelik yapılan düzenlemedir. Bu düzenlemede yerel yönetimlerin ortaklığında kurulabilecek olan yenilenebilir enerji kooperatiflerine duyulan ihtiyaç vurgulanmıştır. Türkiye'de yenilenebilir enerji kooperatifi kurulabilmesine yönelik diğer önemli bir düzenleme ise 2 Ekim 2013 tarihli ve 28783 sayılı Resmi Gazete'de yayınlanan "Elektrik Piyasasinda Lisanssız Elektrik Üretimine İlişkin Yönetmelik"tir. İlgili Yönetmeliğe 2016 yılında yapılan düzenlemeler ile yenilenebilir enerji kooperatifi çatısı altında tüketimlerini birleştiren yerel yönetimlere ve vatandaşlara, tüm yenilenebilir kaynaklar bazında 1 MW'tan 2 MW'a kadar kapasite imkânı getirilmiştir. Bu alana yönelik diğer önemli bir düzenleme ise 2013 yılında İller Bankasının, belediyelerin enerji giderlerini azaltmak üzere yapacakları yenilenebilir enerji kaynaklı enerji üretim yatırımlarına kredi vermeye başlamasidir.

Tüm bu düzenlemeler ile beraber Türkiye'de 2017 yılı itibariyle 2 tanesi yerel yönetimlerin ortaklığında, 22 tanesi de özel girişim desteği ile toplam 24 adet yenilenebilir enerji kooperatifi kurulmuştur. Yukarıda da vurgulandığı üzere ülkemizde şu anda yerel yönetimlerin desteği ile kurulan 2 yenilenebilir enerji kooperatifi vardır. Bunlardan ilki Nilüfer Yenilenebilir Enerji Kooperatifi diğeri ise Seferihisar Yenilenebilir Enerji Kooperatifi'dir. Türkiye için iyi uygulama örneği oluşturabilecek olan Nilüfer ve Seferihisar ilçe 
belediyelerinin kendi yörelerinde kurdukları yenilenebilir enerji kooperatifleri, hem kurum personeli hem de yöre yaşayanları tarafından sahiplenilmiştir. Nilüfer Yenilenebilir Enerji Kooperatifi ilk aşamada 7 kurucu üye ile belediye arazisi üzerinde kurulmuş ve hızla üye sayısını arttırmıştır. Genellikle belediyede çalışanlarının bir araya gelerek kurdukları bu girişim, rüzgâr enerjisini de hedef olarak koymuştur (Nilüfer İlçe Belediyesi, 2018). Seferihisar İlçe Belediyesi bünyesinde 7 kurucu ortak ile kurulan kooperatifin ise temel amacı, kamu alanlarının enerji ihtiyacını yenilenebilir kaynaklardan üretmektir. Seferihisar Yenilenebilir Enerji Kooperatifi de belediye arazisi üzerinde kurulmuştur (Seferihisar İlçe Belediyesi, 2018). Her iki kooperatif de 2019 yılı itibariyle üretime geçerek, yerel ölçekte önemli bir yenilenebilir enerji üretim potansiyeli yaratacaktır. Yerel yönetimler ortaklığında kurulan ve kurulacak olan bu kooperatif modelleri birçok avantaj1 ve kolaylığı da beraberinde getirmektedir. Yerel yönetimler ortaklığındaki yenilenebilir enerji kooperatiflerinin kurulumu için gerekli olan arsa tahsisinin kolaylığı, araç, gereç ve finansal destek sistemlerinin belirlenmesi, İller Bankası aracılı̆̆ı ile kredi alım imkanının olması, yerel yönetimler eliyle daha hızlı gerçekleşmekte ve bürokrasinin bu alandaki engellerine daha az takılmaktadır.

Sonuç olarak enerji dönüşümünün kaçınılmaz olduğu bu yeni dönemde, yerel yönetimlere büyük bir görev ve sorumluluk düştüğü açıtır. Bu çalışma kapsamında da yenilenebilir enerji alanında yerel yönetimler için mevcut durum ve iyi uygulama örnekleri üzerinden iki aşamalı bir yol haritası önerilmiştir. Buna göre planlama alanında, i) yerel yönetimler tarafından yörenin yenilenebilir enerji alanında stratejik öncelik ve hedeflerini gözeten, kapsayıcı bir stratejik planlama sürecinin işler hale getirilmesi, uygulama alanında ise ii) yerel yönetimlerin ortaklığında, vatandaş odaklı yenilenebilir enerji kooperatif modelinin hayata geçirilmesi önerilmektedir. $\mathrm{Bu}$ öneriler ile birlikte yerel yönetimlerin, Türkiye'nin enerji dönüşümüne ve iklim değişikliğine uyum sürecine önemli bir katkı sağlayacağı düşünülmektedir. 


\section{Extended Abstract}

*

\section{Renewable Energy in Local Governments' Policies}

\author{
Asmin Kavas Bilgiç \\ TEPAV \& Osman Gazi University \\ ORCID: 0000-0001-8319-7950
}

\author{
Deniz Başoğlu Acet \\ METU \\ ORCID: 0000-0003-1918-1756
}

\section{Aim of the Study}

Following the 1973 Oil Crisis, almost all the countries started to put increased emphasis on their energy needs Since then, especially developed countries have commenced a quest for implementing policies aimed at diversifying their energy sources, creating alternative energy resources and using energy efficiently. Factors such as urbanization, diversification of information technology, change of production and consumption habits cause an increase in the demand for energy. In order to achieve sustainable growth, various countries have prioritized meeting energy demand as optimally as possible as their main goal. Correspondingly, countries that do not meet the energy demand within its borders become subject to external dependence in energy. Empirical research conducted in recent years show that, one of the most important obstacles in front of industrialization and economic development is the high level of dependence on foreign sources for energy. In turn, this also demonstrates the direct proportionality between growth and energy consumption as well. Moreover, it is anticipated that further growth can take place if this dependence on foreign resources for energy can be limited to minimum. With the rapid urbanization due to a wave of migration from rural to urban areas and industrialization since 1950s, need and demand for energy is ever-increasing in Turkey. For Turkey, who is importing approximately 75 percent of the demanded energy; external dependence, the expenditure of the income from exports for the energy imports, large share of fossil fuel-based energy resources is in between the important risks threatening the energy security. To address the 
mentioned goals of minimizing external dependence, and achieving independence in energy as well as developing sustainably, emerging countries including Turkey has accelerated the creation and implementation of policies on alternative energy resources and the efficient use of energy starting from 2000s.

As of the 2000s, significant adjustments were made to the legal framework and institutional areas in Turkey aimed at meeting the increasing energy demand from local resources, improving energy infrastructure, reducing the burden of energy costs on economy and energy efficiency both for effective use of energy and to decrease the burden on environment. The legal arrangements that have been made since 2001 reflect a different view from the centralist approach, which require multi-disciplinary work and the need to form multi-partner and multi-stage structures. Accordingly, these legal arrangements and related actions cannot be carried out adequately enough by central government bodies and their provincial units alone. Considering that approximately 93 percent of the population in Turkey today is living within municipal boundaries, of which 77.6 percent live in metropolitan municipalities and the remaining 22.4 percent live within other municipal boundaries, local governments have a great deal of responsibilities related to energy supply and efficiency, as well as the realization of the energy policies that can be accelerated from part to whole and from local to center. It is common in the international arena for energy production and efficiency fall under the responsibility of local governments. In countries such as Germany, New Zealand, Denmark and France, local governments hold control of the vast majority of renewable energy investments, the decentralized energy infrastructures, and begin to take over local energy infrastructures, therefore ending special privileges. On the other hand, in Turkey, the acts of local governments, which are liable to Metropolitan Municipality Act with the law no. 5216, Municipal Law with the law no. 5393 and Special Provincial Administration Law with the law no. 5302; according to the findings of the research show.that the plans commonly ignore the strategic priorities and objectives of the region and falls short in going beyond the improvement of institutional performance indicators in terms of energy,

The main purpose of this study titled "Energy Policies in Local Governments" is to determine the energy-related political activity areas of local governments, which have an important role in the implementation of energy policies in Turkey and to contribute to the development of a new political dialogue that will engage all related stakeholders. 


\section{Methodology}

Within the scope of this research, in-depth investigation methodology will be utilized. Energy policies and activity areas of 30 metropolitan municipalities, which host a major population and energy requirement of Turkey; (1) strategic plans and regularized annual performance programs and (2) activity reports between the years of 2014 and 2019 will be discussed and comparatively analyzed with international examples of best practices. During the research, references to sustainable use of energy and renewable energy policies on the local government level will be dedicatedly investigated.

\section{Findings/First Results}

At the consideration section of findings, it will be reflected that (1) energy policies and activity areas of 30 metropolitan municipalities in Turkey are inadequate and (2) most of these municipalities comprise of goals and policies (related to energy) that cannot go beyond the improvement of institutional performance indicators.

\section{Conclusion}

At the conclusion part, a two-stage roadmap for Turkey will be recommended according to the good practices as resources of the evaluation of local government performances and as standardization of service areas on energy for local governments, will be constituted while considering of policies, applications, and objectives that aimed at sustainable energy scope of local governments in the examples of Turkey and international best practices. As mentioned above, in Turkey, which is dependent on outside energy resources at a rate of approximately \%75, local governments have an important place in carrying ot energy policies into effect. Within the context of this research, the aim is to put emphasis on the decentralization of activities on sustainable energy efficiency; and on the development of relevant actions, policies, and strategies by local governments within the scope of mobilization and monitoring of local works. 


\section{Kaynakça/References}

Adıyaman, Ç. (2012). Türkiye'nin yenilenebilir enerji politikaları. Doktora Tezi Niğde Üniversitesi, Niğde.

Avrupa Parlamentosu [AP]. (2018). Report on the role of EU regions and cities in implementing the COP 21 Paris Agreement on climate change (2017/2006(INI). A8-0045/2018). 11 Kasım 2018 tarihinde http://www.europarl.europa.eu/sides/getDoc.do?pub-

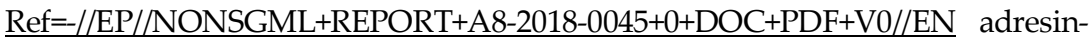
den erişildi.

Birleşmiş Milletler [BM]. (2016). Paris Anlaşması. (1. Bsm). (I. Özkaya-Özlüer, E. Turhan, F. Özlüer ed.), (Y. B. Çamurdan Çev.) Ekoloji Kolektifi Derneği. 11 Kasım 2018 tarihinde http://ekolojikolektifi.org/wp-content/uploads/2017/11/Paris Anlasmasi-ISBN-978-605-83799-1-6.pdf adresinden erişildi.

Birleşmiş Milletler [BM]. (2018). World urbanization prospects: The 2018 revision, key facts. 11 Kasım 2018 tarihinde https://population.un.org/wup/Publications/Files/WUP2018-KeyFacts.pdf adresinden erişildi.

Birleşmiş Milletler Kalkınma Programı [BMKP]. (2018) Sürdürülebilir kalkınma hedefleri. $10 \mathrm{Kasim} 2018$ tarihinde http://www.tr.undp.org/content/turkey/tr/home/sustainable-development-goals.html adresinden erişildi.

Ćetković, S. ve Buzogány, A. (2016). Varieties of capitalism and clean energy transitions in the European Union: When renewable energy hits different economic logics. Climate Policy, 16(5), 642-657. (erişim tarihi 07.12.2018) https://www.tandfonline.com/doi/full/10.1080/14693062.2015.1135778 adresinden erişilmiştir.

City of Paris ve Green Parks and Environment Urban Ecology Agency. (2018). Paris climate action plan: Towards a carbon neutral city and \%100 renewable energies. 22 Ekim 2018 tarihinde https://api-site-cdn.paris.fr/images/101081 adresinden erişildi.

DGRV. (2016). DGRV annual survey of energy cooperatives: 2015 - Energy cooperatives. 10 Kasim 2018 tarihinde https://www.dgrv.de/weben.nsf/272e312c8017e736c1256e31005cedff/e7b7b885ccf6c6e8c1257e84004f9047/ \$FILE/Survey_Energy_Cooperations_2015.pdf adresinden erişildi.

Enerji Atlası (2018). Enerji Atlası. (erişim tarihi.15.07.2018) tarihinde http://www.enerjiatlasi.com/ adresinden erişildi.

Enerji ve Tabii Kaynaklar Bakanlığı [ETKB]. (2012). Dünyada ve Türkiye'de enerji görünümü. 10 Kasım 2018 tarihinde www.enerji.gov.tr/Dunyada ve Turkiyede Enerji Gorunumu.pdf adresinden erişildi.

eni Fransa. (2017). The electricity market in France. 9 Kasım 2018 tarihinde https://www.eni.com/en_FR/products-services/electricity/electricity_market/electricity market.shtml adresinden erişildi.

Fouquet, R. ve Pearson, P. J. (2012). Past and prospective energy transitions: Insights from history. Energy Policy, 50, 1-7. https://doi.org/10.1016/j.enpol.2012.08.014

Onurbaş-Avcioğlu, A. (2017) Yenilenebilir enerji kaynakları ve teknolojileri. Ayten Onurbaş Avcıoğluna ait 2017 Ders Notları, Ankara Üniversitesi, Ziraat Fakültesi, Tarım Makinaları ve Teknolojileri Bölümü. (05.11.2018). https://acikders.ankara.edu.tr/pluginfile.php/18473/mod_resource/content/0/YEN\%C4\%BOLE- 
NEB\%C4\%B0L\%C4\%B0R\%20ENERJ\%C4\%B0\%20KAYNAK-

LARI\%20VE\%20TEKNOLOI\%C4\%BOLER\%C4\%B0\%202.pdf adresinden erişildi.

International Energy Agency (IEA). (2016a). Energy technology perspectives 2016 - towards sustainable urban energy systems: Executive summary. 10 Kasim 2018 tarihinde https://www.iea.org/publications/freepublications/publication/EnergyTechnologyPerspectives2016 ExecutiveSummary EnglishVersion.pdf adresinden erişildi.

International Energy Agency [IEA]. (2016b). Energy policies of tea countries: France. 2016 Review. 11 Kasım 2018 tarihinde https://www.iea.org/publications/freepublications/publication/Energy_Policies_of IEA_Countries_France_2016_Review.pdf adresinden erişildi.

International Energy Agency [IEA]. (2018). Key world energy statistics. 11 Kasım 2018 tarihinde https://www.iea.org/statistics/kwes/ adresinden erişildi.

International Renewable Energy Agency [IRENA]. (2016a). Note of the Director-General Renewable Energy in Urban Settings IRENA Input to the New Urban Agenda. Twelfth meeting of the Council Abu Dhabi, 1 - 2 November 2016. 23 Ekim 2018 tarihinde https://www.irena.org/-/media/Files/IRENA/Agency/About-IRENA/Council/Twelth-Council/C 12 DN 2 RE-and-Cities.pdf adresinden erişildi.

International Renewable Energy Agency [IRENA]. (2016b). Renewable energy in cities:International renewable energy agency (IRENA), Abu Dhabi. 23 Ekim 2018 tarihinde http://www.irena.org/-/media/Files/IRENA/Agency/Publication/2016/IRENA Renewable Energy in Cities 2016.pdf adresinden erişildi.

Klagge, B., ve Meister, T. (2018). Energy cooperatives in Germany-an example of successful alternative economies?. Local Environment, 23(7), 697-716. https://www.tandfonline.com/doi/abs/10.1080/13549839.2018.1436045

Kuittinen, H ve Velte, D. (2018). Mission-oriented REI policies: In-depth case studies Case Study Report: Energiewende. 11 Kasım 2018 tarihinde https://ec.europa.eu/info/sites/info/files/mission oriented $\mathrm{r}$ and i policies case study report energiewende-de.pdf adresinden erişildi.

le Dû, S. (2017). Towards 32\% renewable energy in 2030: French public policies for renewables. 22 Ekim 2018 tarihinde https://www.tresor.economie.gouv.fr/Articles/6d47bddb-

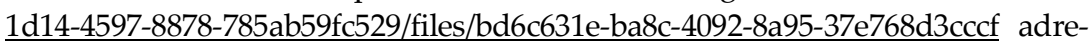
sinden erişildi.

Ministry of Environment, Energy and Sea of France [MEEM]. (2016, Haziran). Energy transition for Green Growth Act in action: Regions - Citizens - Business. 23 Ekim 2018 tarihinde https://www.ecologique-solidaire.gouv.fr/sites/default/files/Energy

Nilüfer İlçe Belediyesi (2018). Yenilenebilir enerji kooperatifi. 15.07.2018 tarihinde http://www.nilufer.bel.tr/haber-4632-nilufer_yenilenebilir_enerji_uretim_kooperatifinde genel kurul heyecani\#PopupGoster[popup]/0/ adresinden erişildi.

Ohlhorst, D. (2015). Germany's energy transition policy between national targets and decentralized responsibilities. Journal of Integrative Environmental Sciences, 12(4), 303-322. Erişim tarihi https://www.tandfonline.com/doi/full/10.1080/1943815X.2015.1125373 adresinden erişilmiştir. 
Onurbaş-Avcıoğlu, A. (2017). Yenilenebilir enerji kaynakları ve teknolojileri: Enerji kaynakları Onurbaş Avcıoğluna ait 2017 Ders Notları, Ankara Üniversitesi, Ziraat Fakültesi, Tarım Makinaları ve Teknolojileri Bölümü. Online site: 10 Kasım 2018 tarihinde

Organisation for Economic Co-operation and Development [OECD]. (2016, Ekim). OECD environmental performance reviews: France 2016. Paris:OECD Publishing, 23 Ekim 2018 tarihinde http://dx.doi.org/10.1787/9789264252714-en adresinden erişildi.

REN21. (2017). Renewables 2017 global status report. 11 Kasım 2018 tarihinde http://www.ren21.net/wp-content/uploads/2017/06/17-8399 GSR 2017 Full Report 0621 Opt.pdf adresinden erişildi.

Seferihisar İlçe Belediyesi (2018). Yenilenebilir enerji kooperatifi. 15.07.2018 tarihinde http://www.seyeko.web.tr/ adresinden erişildi.

Seto, K.C., Dhakal, A., Bigio, H., Blanco, G.C., Delgado, D., Dewar, L., Huang, A., .... , Ramaswami, A.. (2014) human settlements, infrastructure and spatial planning. ( Edenhofer, O., R. Pichs-Madruga, Y. Sokona, E. Farahani, S. Kadner, K. Seyboth, A. Adler, I. Baum, S. Brunner, P. Eickemeier, B. Kriemann, J. Savolainen, S. Schlömer, C. von Stechow, T. Zwickel and J.C. Minx Der.). Climate Change 2014: Mitigation of Climate Change. Contribution of Working Group III to the Fifth Assessment Report of the Intergovernmental Panel on Climate Change içinde (s. 923 -1000). Cambridge University Press, Cambridge, United Kingdom ve New York, NY, USA. 10 Kasim $2018 \quad$ tarihinde https://www.ipcc.ch/pdf/assessment-report/ar5/wg3/ipcc wg3 ar5 chapter12.pdf adresinden erişildi.

The International Renewable Energy Agency (2017). The International renewable energy statistics. 11.09.2018 tarihinde https://www.irena.org/publications/2017/Jul/Renewable-Energy-Statistics-2017 adresinden erişildi.

The World Bank. (2015). Energy imports 12.07.2018 tarihinde https://data.worldbank.org/indicator/EG.IMP.CONS.ZS?locations=TR adresinden erişildi.

Van de Ven, D. J. ve Fouquet, R. (2017). Historical energy price shocks and their changing effects on the economy. Energy Economics, 62, 204-216. Erişim tarihi https://www.sciencedirect.com/science/article/pii/S0140988316303553 adresinden erişilmiştir.

Van Staden, M. (2017). Sustainable energy transition: Local governments as key actors. (T. S. Uyar, Der.) Towards 100\% Renewable Energy içinde (s.17 - 25). Springer, Cham. 10 Kasım 2018 tarihinde https://link.springer.com/chapter/10.1007/978-3319-45659-1_2 adresinden erişildi.

Vidalenc, E. (2017). Local energy planning in France: a way to reinforce energy transition. European Council for an Energy Efficient Economy için Konferans Bildirisi. 23 Ekim 2018 tarihinde https://www.eceee.org/library/conference proceedings/eceee Summer_Studies/2017/3-local-action/local-energy-planning-infrance-a-way-to-reinforce-energy-transition/ adresinden erişildi.

Yılmaz, M, (2012) Türkiye'nin enerji potansiyeli ve yenile-nebilir enerji kaynaklarının elektrik enerjisi üretimi açısından önemi. Ankara Üniversitesi Çevrebilimleri Dergisi, 4(2), 33-54 
Asmin Kavas Bilgiç, 2008 yılında İhsan Doğramacı Bilkent Üniversitesi Mimarlık Fakültesi Kentsel Tasarım ve Peyzaj Mimarlığı Bölümü'nden mezun oldu. 2011 y1lında Ankara Üniversitesi Siyasal Bilgiler Fakültesi Siyaset Bilimi ve Kamu Yönetimi Kent ve Çevre Bilimleri Anabilim Dalında, yüksek lisans derecesi aldı. 2012 yılında Ankara Üniversitesi Siyasal Bilgiler Fakültesi Siyaset Bilimi ve Kamu Yönetimi Kent ve Çevre Bilimleri Anabilim Dalında, doktoraya başladı 19 Haziran 2017 tarihinde tamamladı ve Doktor unvanını aldı. TOBB Üniversitesi ve Eskişehir Osmangazi Üniversitesi'nde yarı zamanlı dersler veren Asmin Kavas, Türkiye Ekonomi Politikaları Araştırma Vakfı Şehir ve Bölge Çalışmaları Programlarında politika analisti olarak çalışmaktadır.

Akademik İlgi Alanları: Yerel yönetimler, toplumsal cinsiyet eşitliği, kentleşme politikaları, yenilenebilir enerji politikaları

Asmin Kavas Bilgiç, In 2008, she graduated from İhsan Doğramacı Bilkent University, Faculty of Architecture, Department of Urban Design and Landscape Architecture. In 2011, she received her MA in Ankara University Faculty of Political Sciences and Public Administration Department of Department of Urban, Environment and Local Government Policies. 2012, she started her PhD in Ankara University Faculty of Political Sciences and Public Administration Department of Department of Urban, Environment and Local Government Policies. On June 19, 2017 she completed her Ph.D. Asmin Kavas who gives parttime lectures at TOBB University and Eskişehir Osmangazi University, has been working as a policy analyst in Urban and Regional Studies Program in The Economic Policy Research Foundation of Turkey.

Academic Interests: Local governments, social gender equality, urbanization policies, renewable energy policies

E-mail: asminkavas@gmail.com, asmin.kavas@tepav.org.tr

Deniz Başoğlu Acet, 2008 yılı İhsan Doğramacı Bilkent Üniversitesi Endüstri Mühendisliği mezun olmuştur. 2017 yılında Orta Doğu Teknik Üniversitesi Yer Sistem Bilimleri Bölümü'nde yüksek lisans çalışmasını tamamladı. Mevcut durumda Ankara' da kurulu bir yenilenebilir enerji firması olan Tardis Enerji Ltd. Şti.'nin kurucu ortağı ve İş Geliştirme Sorumlusu olarak görev yapıyor. Aynı zamanda, Orta Doğu Teknik Üniversitesi Fen Bilimleri Enstitüsü Yer Sistem Bilimleri Bölümü'nde Doktora çalışmalarına devam ediyor.

Akademik ilgi alanları: Ekosistem hizmetleri, gıda-su-enerji bağı, yenilenebilir enerji, enerji dönüşümü, yenilenebilir enerji politikaları

Deniz Başoğlu Acet, In 2008, she graduated from İhsan Doğramacı Bilkent University, Department of Industrial Engineering. In 2017, she received her MA at the Middle East Technical University, Institute of Science, Department of Earth Systems Sciences. She is working as a business development manager and cofounder at Tardis Energy Ltd., a renewable energy company. She continues her 
doctoral studies at the Middle East Technical University, Institute of Science, Department of Earth Systems Sciences.

Academic Interests: Ecosystem services, food-water-energy bond, renewable energy, energy transition, renewable energy policies

E-mail: deniz@tardisenerji.com, denizbasoglu@tardisenerji.com 